\title{
WALKI ODDZIALU WYDZIELONEGO PPLK. MARIANA FRYDRYCHA Z JEDNOSTKAMI 30 DYWIZJI PIECHOTY WEHRMACHTU O UTRZYMANIE PRZEPRAWY MOSTOWEJ W UNIEJOWIE W DN. 6-7 WRZEŚNIA 1939 ROKU
}

Zarys treści: W czasie wojny obronnej we wrześniu 1939 roku Uniejów i jego okolice były miejscem zaciętych walk pomiędzy oddziałami polskiej armii „Poznań” i niemieckiej 8 armii. Taktyczne znaczenie Uniejowa związane było ze znajdującą się tutaj przeprawą przez rzekę Wartę, której utrzymanie miało kluczowe znaczenie dla wojsk polskich, maszerujących znad granicy w kierunku Warszawy. Wrogie sobie oddziały stoczyły w tym rejonie walkę o utrzymanie przeprawy mostowej (Polacy), bądź jej zdobycie (Niemcy). Bitwa miała miejsce w dniach 6-7 września, gdy polski Oddział Wydzielony ppłk. Mariana Frydrycha, dowódcy 60 Pułku Piechoty Wielkopolskiej z 25 Dywizji Piechoty, uniemożliwił oddziałom 30 Dywizji Piechoty z 8 armii Wehrmachtu zdobycie i zniszczenie mostu w Uniejowie, a tym samym zapewnił bezpieczeństwo przeprawy oddziałom macierzystej armii. Bitwa miała dwie fazy, pierwszą była zasadzka 2 batalionu 60 pp pod Balinem w dn. 6 września wieczorem. Drugą był kontratak sił niemieckich, rozpoczęty następnego dnia rano. Bitwa pod Uniejowem była wstępem do walk tych samych oddziałów pod Łęczycą (I faza bitwy nad Bzurą). Autorzy po raz pierwszy w polskiej historiografii wykorzystują dokumenty dywizyjne z archiwów niemieckich, identyfikując wojska Wehrmachtu, biorące udział w tych walkach, do szczebla pododdziałów oraz prezentując obraz walk z perspektywy wojsk agresora. Udało się także jednoznacznie wyjaśnić nierozstrzygniętą dotąd w piśmiennictwie kwestię rozbicia przez Niemców 1 batalionu 29 Pułku Strzelców Kaniowskich pod Uniejowem 7 września wieczorem.

Słowa kluczowe: wojna obronna, wrzesień 1939 r., Uniejów, Balin, armia „Poznań”, 8 armia (Niemcy), 25 Dywizja Piechoty, 30 Dywizja Piechoty (Niemcy), ppłk Marian Frydrych, gen. mjr Kurt von Briesen (Niemcy), 60 pułk piechoty

* Tomasz Wójcik, mgr, absolwent Wydziału Filozoficzno-Historycznego Uniwersytetu Łódzkiego, nauczyciel historii, przewodniczący Komisji Społecznej Rady Miejskiej w Uniejowie, e-mail: wojcik.uniejow@gmail.com

** Jacek Boraś, historyk amator, regionalista łączący zainteresowanie przeszłością z pasją do nauki języków obcych, członek Koła Miłośników Dziejów i Tradycji Regionu w Kawęczynie, e-mail: jacek_boras@op.pl 


\section{TAKTYCZNE ZNACZENIE UNIEJOWA DLA WOJSK OBU STRON SYTUACJA W REJONIE UNIEJOWA W PIERWSZYCH DNIACH WOJNY OBRONNEJ 1939 ROKU}

Uniejów we wrześniu 1939 roku był dwukrotnie miejscem intensywnych walk oddziałów polskich z siłami niemieckimi. Po raz pierwszy doszło do nich wieczorem w środę 6 września i kolejnego dnia, w czwartek, aż do godzin popołudniowych. Do starcia doszło w rejonie na południe i południowy-wschód od miasta w pobliżu poduniejowskiej wsi Balin. Po raz kolejny siły armii „Poznań” i 8 armii Wehrmachtu stanęły naprzeciw siebie w nocy z soboty na niedzielę, z 9 na 10 września, zaciekle walcząc na północnych przedmieściach i w samym centrum Uniejowa.

W niniejszym artykule autorzy omawiają dokładnie przebieg walk pod Balinem. Analiza źródeł, zarówno polskich, jak i niemieckich, pozwoliła na odtworzenie zamiarów, ruchów i działań obu stron. W szczególności dotyczy to oddziałów niemieckich, których działania w rejonie Uniejowa były dotąd w polskiej historiografii przedstawiane pobieżnie, a niekiedy wręcz mylnie ${ }^{1}$. Wykorzystanie źródeł niemieckich, zarówno dokumentowych, jak i wspomnieniowych, pozwoliło autorom na wypełnienie tej luki.

Znaczenie taktyczne Uniejowa dla sztabowców obu stron we wrześniu 1939 roku związane było przede wszystkim z mostem nad głównym korytem Warty (a także mniejszymi mostami na starorzeczu rzeki w tym rejonie), będącym dogodną przeprawą zarówno dla ewakuującej się ludności cywilnej, potencjalnie także dla oddziałów Wojska Polskiego, w razie konieczności wycofania się znad granicy w kierunku Warszawy. W ramach opracowanego wiosną 1939 roku planu obronnego „Zachód”, Uniejów znalazł się na skraju obszaru

1 Walki w rejonie Uniejowa były przedstawiane w polskiej historiografii w pracach monograficznych, obejmujących całość kampanii polskiej 1939 roku, bądź koncentrujących się na działaniach armii „Poznań”: Polskie Sity Zbrojne w drugiej wojnie światowej, t. I, Kampania wrześniowa 1939, cz. 2, Przebieg działań od 1 do 8 września, Instytut Polski i Muzeum im. gen. Sikorskiego, Londyn 1986 [dalej: PSZ]; P. Bauer, B. Polak, Armia Poznań w wojnie obronnej 1939, Poznań 1982; W. Rezmer, Armia „Poznań” 1939, Warszawa 1992; J. Korczak, Cóżeś ty za pani... O walkach armii „Poznań” 1-19 września 1939 r., Poznań 1988; B. Polak (red.), Udziat społeczeństwa ziemi kaliskiej w wojnie obronnej 1939 roku, Kalisz 1979. Wszędzie tam jednak działania niemieckie opisywane były w sposób ogólny, pomijający istotne szczegóły. W jeszcze większym stopniu dotyczy to literatury skoncentrowanej na tematyce uniejowskiej, co gorsza nie wolnej od błędów w omawianym zakresie: J. Baranowski, Wojna obronna Polski w 1939 r. i lata okupacji hitlerowskiej, [w:] J. Szymczak (red.), Uniejów. Dzieje miasta, Łódź-Uniejów 1995; W. Szymański, Z kart historii. Wrzesień 1939 r. - Uniejów w ogniu walk, „W Uniejowie” 2000, nr 3; A.Z. Józefowicz, Działania wojenne w Uniejowie we wrześniu 1939 roku, „W Uniejowie” 2005, nr 23. Próbę identyfikacji i szczegółowego opisu strony niemieckiej podjął T. Wójcik: T. Wójcik (red.), Zapamiętane z Brückstädt. Wspomnienia wojenne mieszkańców ziemi uniejowskiej, Uniejów 2014. Niniejszy tekst stanowi kontynuację badań autora, prowadzonych tym razem wspólnie z J. Borasiem. 
operacyjnego armii „Poznań” (dowódca gen. dyw. Tadeusz Kutrzeba), w ramach tzw. przedmościa „Koło”.

W polskim planie obronnym „Zachód” przewidziano dla armii „Poznań” rolę wybitnie defensywną, sprowadzającą się do aktywnego zabezpieczenia skrzydeł armii sąsiadujących („Pomorze” i Łódź”) oraz osłony Poznania i Wielkopolski w celu przeprowadzenia mobilizacji i ewakuacji. Zamysłem niemieckiego planu operacyjnego było zniszczenie głównych sił polskich w rejonie na zachód od linii rzek Wisły i Narwi.

Pomiędzy Uniejowem, znajdującym się w obszarze operacyjnym armii „Poznań”, a Sieradzem, bronionym przez oddziały armii „Łódź” (gen. dyw. Juliusz Rómmel), istniała luka w polskim systemie obronnym, mająca ok. $40 \mathrm{~km}$ szerokości. Uderzający, pomiędzy Uniejowem a Sieradzem, nieprzyjaciel mógł prowadzić działania oskrzydlające obie polskie armie, a przy szczególnie niekorzystnym rozwoju sytuacji, wojska niemieckie mogły znaleźć się w rejonie Warszawy szybciej niż wycofująca się na wschód armia „Poznań”. Doświadczony sztabowiec, jakim był gen. T. Kutrzeba, zdawał sobie sprawę z tego niebezpieczeństwa, o czym informował Naczelnego Wodza, marsz. Edwarda Śmigłego-Rydza.

Do działań w rejonie południowego i środkowego biegu Warty przeznaczona była część sił niemieckiej Grupy Armii „Süd” (Południe) gen. płk. Gerda Rundstedta. Rozkazy dla niej obejmowały wyjście z Opolszczyzny, przełamanie nadgranicznego oporu polskiego, a następnie zdobycie Warszawy, za pomocą szybkich WJ. Lewe skrzydło GA stanowiła 8 Armia (gen. piech. Johannes Blaskowitz), złożona ze stosunkowo szczupłych sił, były to 4 dywizje piechoty, zorganizowane w dwóch korpusach armijnych: X KA - gen. art. Wilhelma Ulexa (24 i 30 DP) oraz XIII KA - gen. kaw. Maximiliana von Weichsa (10 i 17 DP) i zaledwie jedna jednostka szybka (pułk zmot. SS „Leibstandarte Adolf Hitler”). Zestaw zadań tej armii zostawiał jej dowódcy spore pole manewru, przewidywał bowiem zarówno energiczny atak w rejonie Sieradza, jak i wyczekiwanie na rozwój wypadków w strefie ataku trzonu sił GA i prowadzenie przede wszystkim działań osłonowych. Wyjściowy obszar działań armii rozciągał się od Sulechowa, przez Głogów, Wrocław, Namysłów, Milicz po Wschowę i miał łącznie ok. 220 km szerokości. Generał J. Blaskowitz za pierwszorzędne uznał natarcie. Oba podległe jego dowództwu korpusy armijne uderzyć miały w wąskim pasie około $30 \mathrm{~km}$ pomiędzy Twardogórą a Sycowem. Główny atak prowadzić miał XIII KA wraz z pułkiem L-AH (SS-Obergruppenführer ${ }^{2}$ Josef Dietrich). Lewoskrzydłowy X KA (tylko 24 DP wraz z oddziałami korpuśnymi) osłaniać miał działania głównych sił armii. 30 DP (gen. mjr. Kurt von Briesen) przydzielono rolę odwodu dowódcy armii, z zadaniem osłony od północy. Skoncentrowanie tej dywizji przed atakiem na Polskę miało miejsce w okolicach Trzebnicy na Dolnym Śląsku. Główna masa

2 Odpowiednik generała. 
dywizji przekroczyła granicę dopiero 3 września, posuwając się trasą Międzybórz - Chojnik - Antonin. W śladzie 30 DP podążać miały odwody GA „Süd”, czyli 213 i $221 \mathrm{DP}^{3}$.

Niepokojące przewidywania gen. T. Kutrzeby okazały się słuszne, bowiem niemiecka 8 armia już 3 września dotarła siłami XIII KA w rejon Sieradza, by stamtąd próbować wyjść w rejon Uniejowa, oskrzydlając od wschodu oddziały wielkopolskie. Jednocześnie 30 DP Wehrmachtu zajęła okolice, a 4 września sam Kalisz. Zagrożenie dla sił armii „Poznań” na jej prawym, południowym skrzydle stało się więc bardzo realne. Niejako w odpowiedzi, dowódca armii „Poznań” planował zwrot zaczepny i zatrzymanie nieprzyjaciela, atakując z okolic Turku przez Dobrę i Miłkowice w kierunku na południe ${ }^{4}$. Ten słuszny pomysł został jednak odrzucony przez Naczelnego Wodza, który nakazał gen. T. Kutrzebie przegrupowanie wojsk na główną linię obrony, co oznaczało przejście 25 DP w rejon przedmościa „Koło”, czyli także Uniejowa.

Prowadzone rozpoznanie lotnicze utwierdzało polskich dowódców w przekonaniu, że realne jest zagrożenie uchwycenia przeprawy mostowej w Uniejowie przez szybkie, zmotoryzowane oddziały nieprzyjaciela ${ }^{5}$. Utrata przeprawy mogła oznaczać, że oddziały kaliskiej 25 DP forsować będą poważną przeszkodę, jaką była rzeka Warta, w obliczu nieprzyjaciela. Dowódca dywizji, gen. dyw. Franciszek Alter, nakazał swoim podwładnym najpierw rozpoznać rejon Uniejowa, później dozorować most. $\mathrm{W}$ dn. 4 września po godz. 11.00 do Uniejowa dotarł 2 pluton 31 kompanii czołgów rozpoznawczych (ppor. Czesław Trzeciak), nie zastając w mieście żadnych pododdziałów polskich ani nieprzyjacielskich ${ }^{6}$. W godzinach południowych przewożone z Turku autobusami (od godz. 11.30) pododdziały 2 batalionu 60 pp mjr. Edwarda Rukszana (bez jednej kompanii i $6 \mathrm{ckm}$ ) przystąpiły do organizacji obrony przeprawy mostowej w Uniejowie ${ }^{7}$. Wkrótce roz-

3 Szerzej na ten temat zob. W. Rezmer, dz. cyt., s. 80-83. Oddział Rozpoznawczy 221 DP, dowodzonej przez gen. por. Johanna Pflugbeila, odpowiedzialny jest za masakrę cywilów i zniszczenia centrum Uniejowa podczas walk z polskim 6 Pułkiem Ułanów Kaniowskich w niedzielę, 10 września. Zob. T. Wójcik, dz. cyt., s. 19 i niżej.

4 W. Rezmer, dz. cyt., s. 144-147.

5 Rozpoznanie w rejonie Uniejowa prowadziły załogi zarówno z 33 Eskadry Obserwacyjnej (kpt. obs. Stanisław Zaleski), jak i 34 Eskadry Rozpoznawczej (kpt. obs. Janusz Badowski); D. Sawicka-Miszewska, L. Sawicki, R. Sawicki, Tadeusz Sawicki (1912-1939) - lotnik poległy na ziemi szadkowskiej. Wspomnienie rodziny, „Biuletyn Szadkowski” 2017, t. 17, s. 146-147; W. Kozłowski, Niedoszła akcja armii „Poznań” między Prosna a Warta w 1939 r., „Acta Universitatis Lodziensis. Folia Historica" 1981, nr 3, s. 127-128.

6 CAW, II.13.12. Meldunek dowódcy patrolu nr 2 ppor. Trzeciaka z godz. 11.50.

7 CAW, II.13.12, Meldunek sytuacyjny 60 pp z godz. 12.00, Relacja por. R. Kaczmarczyka, dowódcy 5 kompanii 60 pp, za: K. Szepietowski, 60 putk piechoty na szlaku bojowym Ostrów Wlkp. - Warszawa, [w:] Żotnierze września, Warszawa 1971, s. 116-117. Rozkaz dla 2 batalionu otrzymał szef sztabu pułku, kpt. K. Szepietowski w dn. 4 września w mp dowództwa dywizji w Turku. 
poczęło się intensywne bombardowanie stanowisk polskiej piechoty oraz samego miasta. Prowadzili je lotnicy z niemieckiej 4 Floty Powietrznej (gen. lotnictwa Alexander Löhr), samoloty Luftwaffe atakowały kolumny głównie cywili, przemieszczające się pomiędzy Turkiem a Uniejowem, przeprawę mostową i samo miasto. Wynikiem nalotów były znaczne straty wśród ludności cywilnej, zarówno mieszkańców miasta i okolicy, jak i uciekinierów, a także żołnierzy oraz zniszczone zabudowania ${ }^{8}$. Niemcy nie zdołali jednak osiągnąć celu taktycznego, nie zniszczyli mostu, jedynie silnie uszkodzili jego konstrukcję. Lotnicy Luftwaffe w swoich raportach, ataki na ludność cywilną tłumaczyli tym, że pośród uciekinierów ukryci byli żołnierze z bronią przeciwlotniczą . Nie był to jednak efekt celowego działania polskiego dowództwa, ale równoczesnego korzystania z dróg przez ewakuujących się cywilów i maszerujące oddziały wojskowe. Warto przy tym wspomnieć, że z żołnierskiego punktu widzenia była to dla oddziałów polskich sytuacja niekorzystna, obniżająca morale, wartość bojową i mobilność wojska.

Kolejny dzień, 5 września, przyniósł niekorzystne dla Polaków wydarzenia w rejonie Warty i Sieradza. Nacierający z dużą siłą XIII KA 8 armii przebił się przez pozycje polskie armii „Łódź” w rejonie Warty i Sieradza. Kontynuując atak, oddziały podległe gen. J. Blaskowitzowi, planowały przedrzeć się przez Rossoszycę, Poddębice w kierunku Ozorkowa i Łęczycy, by tam odciąć drogę ku Warszawie armii „Poznań”. Spełniał się zatem najgorszy scenariusz, przewidywany już wcześniej przez gen. T. Kutrzebę. Niemców mogło zatrzymać jedynie zdecydowane przeciwnatarcie armii „Poznań” i uderzenie na Niemców w kierunku Dobrej i Sieradza. Przygotowania do niego wstrzymały jednak kolejne rozkazy Naczelnego Wodza, nakazujące rezygnację z kontrnatarcia i przejście części oddziałów armii „Poznań” w kierunku wschodnim, a więc przeprawy w Uniejowie, a stamtąd ku Warszawie. Utrzymanie uniejowskiego mostu na Warcie stało się w tym momencie kluczowym zadaniem dla całego prawego skrzydła wojsk gen. T. Kutrzeby.

8 Już wczesnym popołudniem 2 batalion 60 pp stracił 5 poległych i kilkunastu rannych. Liczby ofiar cywilnych nie sposób podać, ale było to co najmniej kilkadziesiąt osób. Szerzej na ten temat pisał T. Wójcik, Skrwawione miasto. Uniejów i jego region w czasie wojny obronnej 1939 roku, „Biuletyn Uniejowski” 2018, t. 7, s. 50 i n.

9 M. Emmerling, Luftwaffe nad Polska 1939. Cz. II: Kampfflieger, Gdynia 2005, s. 96. 


\section{PIERWSZA FAZA WALK. BÓJ OW PPŁK. MARIANA FRYDRYCHA Z JEDNOSTKAMI „GRUPPE ADELHOCH” POD BALINEM 6 WRZEŚNIA WIECZOREM}

Do obrony przeprawy w Uniejowie powołano Oddział Wydzielony pod dowództwem ppłk. Mariana Frydrycha (określanego jako „dowódca Uniejów”), w składzie jego $60 \mathrm{pp}^{10}$, wzmocnionego 1 batalionem 29 pp (mjr Stanisław Szczygieł) i artylerią 25 pal (1 dywizjon mjr. Stanisława Boryczki i 8 bateria kpt. Jerzego Turaszwiliego). 3 batalionowi 25 pal (ppłk Józef Nowak) przydzielono zadanie osłony oddziałów dywizji w czasie przemarszu wzdłuż szosy z Turku do Uniejowa, a 25 bateria artylerii plot. kpt. Pawła Żnińskiego (wsparta samodzielną kompanią ckm $\mathrm{nr} 73$ por. Wąsika) miała strzec przeprawy mostowej ${ }^{11}$. Gros sił oddziału ppłk. M. Frydrycha osiągnęło Uniejów o świcie 5 września. Ze względu na forsowny marsz żołnierzom dokuczały otarcia i rany stóp, pułkowa służba medyczna doraźnie pomagała im, rozdając przetopiony łój, zakupiony u uniejowskich rzeźników. Budynek poczty przy ul. Bogumiła stał się siedzibą dowództwa 60 pułku $^{12}$. W południe do Uniejowa przyjechał płk. dypl. Julian Skokowski, dowódca piechoty dywizyjnej 25 DP, nakreślając konieczność utrzymania w polskich rękach drożnego mostu w Uniejowie, przynajmniej do godziny 14.007 września, czyli do momentu planowanego ukończenia przeprawy przez oddziały Wielkopolskiej BK i całej $25 \mathrm{DP}^{13}$.

Realizując niezwłocznie powierzone zadanie, 5 września ppłk M. Frydrych obsadził most i jego przedpole o szerokości $11 \mathrm{~km}$ (do ujścia Neru) 1 batalionem 60 pp (mjr Aleksander Fiszer), wzmocnionym 5 batalionem ckm i broni towarzyszących (mjr Alfons Kubosz). 2 batalion swojego pułku skierował w rejon Bud Uniejowskich (dziś ul. Sienkiewicza) z zadaniem ubezpieczenia od południa potencjalnego kierunku uderzenia przeciwnika, idącego z kierunku przeprawy w Popowie. Wsparcie artyleryjskie zapewniał 1 dywizjon 25 pal. 2 kompania (por. Antoni Okniński) odesłana została jako odwód dowódcy pułku do lasu

${ }^{10}$ Rozkaz tworzący OW (ustny lub niezachowany pisemny), wydany najpewniej przez dowódcę dywizji, otrzymał wieczorem 4 września w Turku szef sztabu 60 pp; K. Szepietowski, dz. cyt., s. 117. Zob też CAW, II.13.12, Ogólny rozkaz operacyjny dowódcy 25 DP na dzień 5 września, część I i II. Według codziennego raportu stanów liczebnych z dn. 6 września 60 pp liczył wtedy 92 oficerów, 542 podoficerów i 2760 szeregowców. Odpowiadało to zakładanemu stanowi bojowemu, CAW, II.13.12 Codzienny raport stanów bojowych [25 DP].

${ }^{11}$ CAW, II.13.12, Meldunek sytuacyjny dowódcy artylerii dywizyjnej 25 DP.

12 PISM, B.I.37D, Relacja ppor. lek. M. Natkańskiego, k. 3-4.

${ }^{13}$ K. Kuźmiński, Dziennik dowódcy kompanii, [w:] Wspomnienia z wrześniowych dni. Wielkopolanie o kampanii wojennej 1939 roku, opr. E. Makowski, Wydawnictwo Poznańskie, Poznań 1975, s. 189. 
Wielenin $^{14}$. Nie zaniedbano rozpoznania. Podpułkownik M. Frydrych słusznie spodziewał się ataku Niemców na lewym skrzydle swojego oddziału, czyli wzdłuż wschodniego brzegu Warty. Na południe, szosą w kierunku Balina i Poddębic został wysłany na rozpoznanie pluton kolarzy, a drogą na Ozorków - pluton zwiadowców konnych. Po dwóch godzinach pluton kolarzy powrócił do Uniejowa, a jego dowódca, ppor. Czesław Kierzek, zameldował, że został ostrzelany z broni maszynowej w pobliżu wsi Niewiesz Kolonia. Siły nieprzyjaciela ustalić nie mógł. Stwierdził tylko, że był to oddział motocyklistów. Na kierunku Uniejów - Ozorków nieprzyjaciela nie stwierdzono ${ }^{15}$. W wyniku intensywnych nalotów most uległ uszkodzeniom (był ,załamany i opadły do rzeki”), wciąż jednak mógł pełnić funkcję przeprawy ${ }^{16}$. Aby przyspieszyć przeprawę wojsk polskich, most zamknięto dla cywilnych uchodźców. Mimo starań nie udało się uniknąć demobilizującego przemieszania kolumn wojskowych z cywilami i grupami żołnierskich rozbitków, szukających macierzystych oddziałów ${ }^{17}$.

Wtorek, 5 września, przyniósł najintensywniejsze naloty. Ataki z powietrza trwały od świtu. Nie zmieniły się ich cele - były nimi kolumny uciekinierów, wypełniające drogę pomiędzy Turkiem a Uniejowem oraz sama przeprawa mostowa przez Wartę ${ }^{18}$.

Zachowanie mostów w Uniejowie, szczególnie największego nad głównym korytem Warty, było zasługą polskich saperów. Żołnierze 25 batalionu saperów (mjr Gracjan Dąbrowski) zjawili się w Uniejowie 6 września nad ranem. Po dokonaniu napraw mostu saperzy zaopatrzyli się w zdobyte przez 60 pp w środę wieczorem auta i motocykle, przejechali do wsi Ostrowsko, by stamtąd po godz. 18 następnego dnia odjechać przez Orzeszków Kolonię i dalej śladem 60 pp do Dąbia ${ }^{19}$.

W dniu 5 września, w godzinach porannych, działająca dotąd przede wszystkim w roli osłony X KA 30 DP gen. mjr. K. von Briesena podjęła działania ofensywne w celu uchwycenia mostu na Warcie pomiędzy Miłkowicami a Popowem.

${ }^{14}$ Wspomina o tym dowódca kompanii, por. Antoni Okuniński (PISM, B.I.37D, Relacja por. A. Okunińskiego, k. 13).

${ }^{15}$ K. Szepietowski, dz. cyt., s. 118.

${ }^{16}$ CAW, II.13.12, Meldunek dowódcy 25 batalionu saperów do dowódcy 25 DP; K. Szepietowski, dz. cyt., s. 117-118; L. Tomaszewski, Wspomnienia z działań 60 putku piechoty we wrześniu 1939 r., [w:] Udziat..., s. 402. PISM, B.I.37G, Sprawozdanie ppor. Cz. Baranowskiego z kampanii wrześniowej 1939 r., k. 5.

${ }_{17}$ A. Zawilski, Bitwa nad Bzura, Warszawa 1969, s. 10.

${ }^{18}$ Szerzej na ten temat: M. Emmering, dz. cyt., s. 106 i 166; tegoż, Luftwaffe nad Polska 1939. Cz. I: Jagdflieger, Gdynia 2002, s. 80-82.

${ }^{19}$ PISM, B. I.37.G, Relacja ppor. Czestawa Baranowskiego, k. 6. 
Dowódca dywizji wyznaczył do tego zadania oddział wydzielony ${ }^{20}$, określony od nazwiska dowódcy jako „Gruppe Adelhoch”, w składzie przyłączonego do składu dywizji zmotoryzowanego 6 batalionu karabinów maszynowych (płk Xaver Adelhoch), wzmocnionego m.in. kompaniami rowerowymi - 5 kompanią $26 \mathrm{pp}$ (por. Wehting) oraz 9 kompanią 46 pp (por. Heinrich Borgmann ${ }^{21}$ ), a także 4 baterią (kpt. Haberbosch) 66 pac (mjr Gustav Hundt). Grupa „Adelhoch” z 3 kompanią 6 batalionu $\mathrm{km} \mathrm{w}$ pierwszej linii zdobyła $\mathrm{w}$ walce przeciw 6 pułkowi strzelców konnych (płk dypl. Stanisław Mossor) most na Warcie między Miłkowicami a Popowem. Rozgromiony w wyniku starcia z przeciwnikiem, dysponującym miażdżącą przewagą w uzbrojeniu oraz zaatakowany z powietrza i zagrożony od południa przez nadchodzącą od strony miasta Warty 24 dywizję piechoty Wehrmachtu, polski 6 psk dokonał po południu 5 września odwrotu w okolice Szadku, odsłaniając tym samym drogę z Popowa na Uniejów ${ }^{22}$. Najprawdopodobniej wysunięty zmotoryzowany patrol należący do 6 batalionu km ostrzelał 5 września z Kolonii Niewiesz wspomniany już polski pluton kolarzy por. Cz. Kierzka. Natychmiast po zdobyciu lekko uszkodzonego mostu łączącego Miłkowice z Popowem, wieczorem i nocą z 5 na 6 września przydzielony do Grupy „Adelhoch” 2 pluton (ppor. Meyer) 2 kompanii saperów (por. Gülich) 30 DP dokonał jego prowizorycznej naprawy ${ }^{23}$.

${ }^{20}$ OW „Gruppe Adelhoch” został powołany rozkazem dowódcy dywizji w dn. 2 września, a zatem jeszcze na terenie Niemiec, zanim dywizja faktycznie wyruszyła na front (3 września). Grupę „Adelhoch” tworzyły pododdziały szybkie, dobrze wyposażone. Przeznaczona była to działań w roli forpoczty sił dywizyjnych; BArch RH26-30/1, Kriegstagebuch Nr 1. 30 Infanterie - Division, s. 12.

${ }^{21}$ Bardzo ciekawe są dalsze losy por. H. Borgmanna. Do 1942 roku był związany z 30 DP. Po odniesieniu rany na froncie wschodnim, został przeniesiony do Akademii Wojskowej w Berlinie, gdzie uzyskał tytuł oficera sztabu generalnego. Pnąc się po kolejnych szczeblach kariery sztabowca, trafił do najbliższego otoczenia Hitlera. Podczas zamachu na Führera 20 lipca 1944 roku był obecny w bunkrze dowodzenia i został ciężko ranny. Niemiecka propaganda w milionowych nakładach powielała zdjęcie, na którym widać Adolfa Hitlera odwiedzającego Borgmanna w szpitalu. Po wyzdrowieniu, już jako pułkownikowi, 2 kwietnia 1945 roku powierzono mu dowodzenie dywizją grenadierów ludowych „Scharnhorst”. Dowodzenia tego nie przejął, gdyż w wyniku ataku lotniczego został ciężko ranny i zmarł 5 kwietnia 1945 roku w jednym z lazaretów w Magdeburgu. Źródło: http://www.lexikon-der-wehrmacht.de/Personenregister/B/BorgmannH. htm [dostęp 12.03.2020].

22 PSZ, s. 197; Z. Gnat-Witeska, 6 Pułk Strzelców Konnych, Pruszków 1988. Wielu szczegółów dostarcza relacja uczestnika tych walk, Stanisława Szostakowskiego: CAW, IX.2.3.134, 6 Pułk Strzelców Konnych im. Hetmana Wielkiego Koronnego Stanisława Żółkiewskiego, mpis, s. $12-15$.

${ }^{23}$ Do naprawy wykorzystano deski ze znajdującej się niedaleko w budowie stodoły oraz ławki z kościoła w Miłkowicach. Informował o tym ówczesny dowódca 2 plutonu 3 kompanii batalionu saperów 30 DP ppor. Alexander Kuhr we wspomnieniowej pracy zbiorowej: Pionier-Bataillon 30. Geschichte 1936-1945, red. A. Ludwigs, Pionier-Kameradschaft, Lübeck bdw. 
Następnego dnia, 6 września o godzinie 11.30, nadciągnęły do Miłkowic czołowe oddziały $30 \mathrm{DP}^{24}$, równocześnie 3 kompania (kpt. Gabler) batalionu saperów (mjr Ziebe) 30 DP wzmocniła most do wytrzymałości 16 ton. Dzięki pracy saperów o godzinie 13.30 główne siły dywizji rozpoczęły przeprawę do Popowa.

O godzinie 12.50 dowódca dywizji, gen. K. von Briesen, rozkazał, aby przebywający w Dobrej oddział rozpoznawczy 30 DP opuścił to miasto, pozostawiając jedynie słabe ubezpieczenia skierowane frontem na północ w kierunku na Uniejów, Przykonę, Turek. Oddział miał natychmiast udać się przez Miłkowice i Popów drogą wzdłuż wschodniego brzegu Warty w kierunku na Uniejów na odległość do $4 \mathrm{~km}$ od Popowa ${ }^{25}$.

W spisanym bezpośrednio po kampanii wrześniowej „Dzienniku wojennym 6 batalionu karabinów maszynowych" znalazły się zapiski, wskazujące na rozdźwięk decyzyjny na szczeblu ponaddywizjnym:

\section{Godzina 13.30 nowe zadanie dla 6 batalionu karabinów maszynowych wydane przez generata von Briesena: batalion ma za zadanie jak najszybciej osiagnać obszar Uniejowa, zdobyć $i$ zabezpieczyć mosty dla nadciagających oddziałów. Batalion wyrusza, lecz o godzinie 14.15 przybywa dowódca [XKA] gen. Ulex $i$ wydaje rozkaz przeciwny: 6 batalion karabinów maszynowych pozostaje w Popowie do dyspozycji dowództwa [X KA]. Batalion zostaje zatrzymany. Ponowny rozkaz gen. von. Briesena: obowiazuje poprzedni rozkaz. Godzina 16.00 batalion wyrusza w kierunku Uniejowa poruszając się bardzo wolno po bezdennie piaszczystych drogach $^{26}$.}

Przytoczony fragment dziennika batalionu opisuje bardzo interesujący, przełomowy dla dalszych wydarzeń w Balinie i Uniejowie, moment. Otóż przybyły dowódca X KA gen. W. Ulex zmienił wydany już rozkaz wymarszu na Uniejów dla 6 batalionu km. Prawdopodobnie chciał go użyć dla wzmocnienia głównej osi ataku prowadzonego w ramach X KA przez $24 \mathrm{DP}$ w kierunku na Wartkowice - Łowicz - Sochaczew. Jednak gen. K. von Briesen zdołał przeforsować swoją koncepcję ataku 30 DP w kierunku Uniejowa z udziałem Grupy „Adelhoch” i jej trzonu, 6 batalionu karabinów maszynowych.

${ }^{24}$ Taką godzinę odnotowano w „Dzienniku wojennym 6 batalionu karabinów maszynowych": BArch, RH 37/6582 Kriegstagebuch vom Polenfeldzug des M.G. - Bataillion 6 (mot) u. später Krad Schtz Btl. 40, s. 26.

${ }^{25}$ BArch, RH26-30/1, Kriegstagebuch nr 1..., s. 30.

${ }^{26}$ BArch, RH37/6582, Kriegstagebuch vom Polenfeldzug..., s. 27. „Bezdennie piaszczyste drogi“ to tzw. „trakt napoleoński”, prowadzący wzdłuż prawego brzegu Warty do Uniejowa. Tędy wiodła droga najkrótsza, w znacznie lepszym stanie była dłuższa droga prowadząca przez Krępę do Uniejowa lub Poddębic, wykorzystana przez oddziały 24 DP. 
Za czołową Grupą „Adelhoch”, jadącą do odległego o mniej więcej $20 \mathrm{~km}$ Uniejowa, organizowały się pozostałe oddziały 30 DP. Po przeprawie przez Wartę w Miłkowicach, gdzie na przyczółku mostowym w Popowie daremnie oczekiwały na atak Polaków, wolno wędrowały w kierunku Uniejowa (były to dwa pułki piechoty, 46 gen. mjr. Waltera Wittke oraz 6 płk. Josepha Reicherta) i Poddębic (26 pp gen. mjr. Moritza Baslera, wraz z podporządkowanymi pozostałymi oddziałami dywizyjnymi).

W czasie, gdy Niemcy z Grupy „Adelhoch”, zmagając się z piaszczystymi drogami, zbliżali się do Uniejowa, na mniej więcej pół godziny przed zachodem słońca, po godzinie 18.00, 2 batalion 60 pp wyruszył marszem ubezpieczonym do wsi Balin, gdzie zaplanowano nocne czaty. Niemcy stracili na czujności i zaczęli zachowywać się wręcz beztrosko. Zmotoryzowana kolumna długości ok. 1 km nadal posuwała się boczną drogą wzdłuż Warty od Popowa przez Księże Młyny i Dominikowice do Uniejowa bez żadnego zabezpieczenia. Podpułkownik Frydrych nakazał 5 kompanii (por. Romuald Kaczmarczyk) i kompanii ppanc swojego pułku (por. Bolesław Zaremba) likwidację niemieckiej kolumny.

Teren starcia to dość szeroka dolina, od południa ograniczona krawędzią wysoczyzny, przypominającą wzgórze. Tam znajdowało się kilka zabudowań niewielkiego przysiółka Kolonia Balin. Od północy dolinę ograniczały zabudowania wsi Balin, od wschodu silnie zadrzewione. Na zachodzie, poza wsią, dolina łączyła się z rozległym nadwarciańskim łęgiem. W najniższym punkcie doliny płynie niewielki strumień. W osi północ - południe biegła szeroka, brukowana droga, prowadząca z Uniejowa w kierunku Szadku bądź Łodzi. Odległość od wsi do Kolonii Balin wynosi około $500 \mathrm{~m}$.

Szpica 5 kompanii na szczycie wzgórza (w Kolonii Balin) zauważyła niemieckie samochody i podpaliła je. Dowódca pułku, z resztą 2 batalionu, obszedł przeciwnika od wschodu i uderzył na Niemców. Sam strzelał z ckm, a następnie poderwał 5 kompanię por. Romualda Kaczmarczyka do szturmu. W dalszym ciągu walk, wraz z dowódcą jednostki, atakowała 4 kompania kpt. Jana Zwolaka, 6 kompania por. Antoniego Baranowskiego pełniła rolę odwodów, idąc w odległości do $3 \mathrm{~km}$ za czołowym pododdziałem (zob. ryc. 1).

Uczestnik tych walk, dowódca 5 kompanii 60 pp, por. R. Kaczmarczyk tak zrelacjonował tę walkę:

6 września o godz. 18.00 na odprawie u dowódcy 2 baonu dostałem rozkaz zaciagnięcia czaty we wsi Balin [...]. W lewo zaciagała czate 4 kompania. Około godz. 18.30 wyruszyłem marszem ubezpieczonym na wyznaczone stanowisko. Po przejściu $2 \mathrm{~km}$ napotkałem na wzniesieniu szosy 3 auta niemieckie. Szpica rozwija się i otwiera ogień, auta się pala. Szpica naciera. Po osiagnięciu wzniesienia widzę cata kolumne zmotoryzowana. Rozkazuję szpicy 
nacierać, wspierając ja 4 ckm z prawej i 2 ckm z lewej strony szosy. 2 pluton skierowatem w prawo do rzeki i stamtąd po przejściu $300 \mathrm{~m}$ polecitem szturmować flankowo na kolumnę. 3 pluton rozwinąt się z lewej strony szosy. Natarcie posuwato się bardzo szybko. Niemcy wycofali się, a faktycznie uciekli, zostawiajac około 60 poległych, 15 rannych $i$ wiele sprzętu ${ }^{27}$.

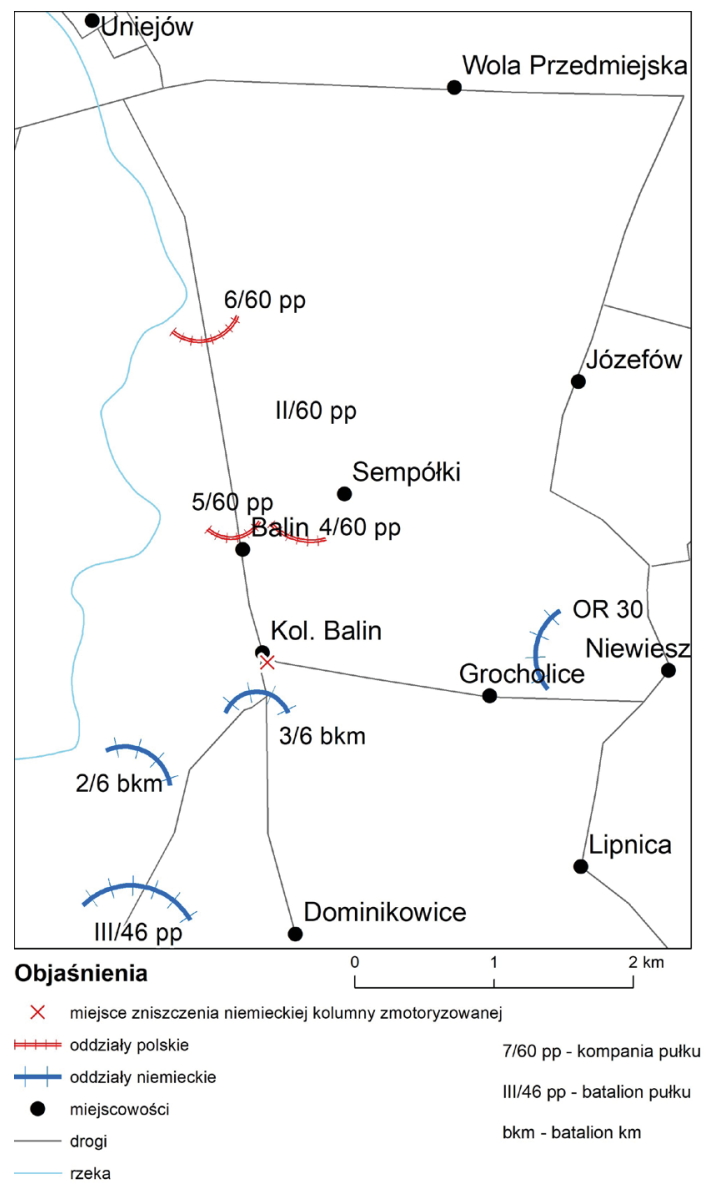

Ryc. 1. Bój OW ppłk. Mariana Frydrycha z jednostkami Grupy „Adelhoch” pod Balinem 6 września Źródło: opracowanie własne

Anonimowy żołnierz Wehrmachtu z 3 kompanii 6 batalionu km w cytowanym już „Dzienniku wojennym” opisał te wydarzenia szczerze, w sposób odległy od wojennej propagandy:

${ }^{27}$ Cytat za K. Szepietowski, dz. cyt., s. 119. 
6 września stat się czarnym dniem dla 3 kompanii podczas kampanii polskiej. Kompania porusza się w następującym porzadku: pluton motocyklowy, oddziat dowodzenia kompanii, 2 pluton, 3 pluton na końcu. Zaczęto sie ściemniać. Docieramy do Kol. Balin, 4 pluton $i$ oddziat dowodzenia kompanii juz prawie przejechaty. Nagle rozpoczyna się morderczy ogień. Szpica kompanii jest $z$ prawej $i$ lewej strony otoczona przez przeciwnika, próbuje jednak trzymać go nisko, by móc się wycofać. 2 pluton na prawo od drogi, 3 na lewo atakuja przeciwnika dysponujacego dobrze ulokowanymi karabinami maszynowymi i granatnikami. Na prawo od nas w charakterze positków zostaje użyty pluton kolarzy. Jest tak ciemno, że nie widzimy na 20 metrów. Nagle Polacy atakuja z flanki z okrzykiem: nie strzelać, własne oddziały! Ci faceci podkradli się aż na naszq wysokość. Większość kolarzy została wzięta do niewoli. 8 towarzyszy broni brakuje u nas. Wiele pojazdów kończy w ogniu, inne trafiaja w ręce Polaków. 2 i 1 kompania przychodza $z$ pomoca. Domy i stogi stomy plona jasnym ogniem, po kolei zostały podpalone pociskami zapalajacymi, byśmy mieli możliwość dalekiej obserwacji przeciwnika ${ }^{28}$.

W tym samym dokumencie, czyli „Dzienniku wojennym” niemieckiego 6 batalionu km znalazł się kronikarski opis walk, pozwalający na określenie ram czasowych i przestrzennych walk:

Godzina $18.15^{29} 3$ kompania [dowodzona przez kpt. Schmidta] ${ }^{30}$, która wraz z 4 plutonem oraz oddziatem dowodzenia kompanii osiagnęta Kol. Balin, gdzie została powitana morderczym ogniem z domów, drzew, piwnic i krzaków traci wszystkie pojazdy 4 plutonu $i$ oddzialu dowodzenia kompanii, tacznie z radiostacjami. Zostaty spalone lub zniszczone granatami. 1 kompania zostaje wysunięta przez Folwark Dominikowice na lasek na wschód od Kol. Balin do ataku. 2. kompania atakuje Balin na lewo od 3 kompanii z lewym skrzydtem na Warcie. Straszne, mało owocne walki nocne przy Kol. Balin.Przeciwnikużywaśrodkówniefair, ludnośćcywilnauczestniczy $w$ walkach z zasadzki, przeciwnik używa urzadzeń rozpylajacych

${ }^{28}$ BArch, RH37/6582, Kriegstagebuch vom Polenfeldzug..., s. 12.

${ }^{29} \mathrm{~W}$ świetle innych relacji, także polskich, początek starcia miał miejsce mniej więcej 30 minut później, ok. godz. 18.45 .

${ }^{30} \mathrm{http}$ ://gliederungundstellenbesetzung.blogspot.com/2008/04/maschinengewehrbataillon-6-mg-btl6-d.html [dostęp: 26.01.2020]. 
gaz ${ }^{31}$. Podczas kontrataku Polaków, którzy szturmują krzycząc po niemiecku: tu wtasne oddziaty, batalion traci podporucznika Bubba przez postrzat $w$ ramię $i$ dwa trafienia bagnetem (ciężko ranny). 3 kompania podczas nocnego ataku traci około 10 zabitych, 5 zaginionych lub wziętych do niewoli; 1 kompania: 2 zabitych, 5 rannych; 2 kompania: 1 zabity, kilku rannych. Około godziny 22.00 zostaje wtaczony Oddziat Rozpoznawczy $30 \mathrm{DP} w$ sile 1 kompanii i 1 kompanii rowerowej w celu wykonania kontrataku. Kontratak zostaje odparty. W kompanii rowerowej poważne straty ${ }^{32}$.

Końcowy fragment walk, po wejściu do działania kompanii OR 30 DP, dobrze zapamiętał kpr. pchor. Tadeusz Pacanowski, dowodzący 8 drużyną odwodowej 6 kompanii 2 batalionu 60 pp. Jego kompania, w chwili gdy walki rozgorzały, znajdowała się znacznie bliżej Uniejowa i na pole boju podążyła wzdłuż Warty, idąc po rozległym, częściowo podmokłym łęgu. I właśnie od zachodu, znad Warty, dotarła do zabudowań Balina. Po latach wspominał, wyraźnie wskazując, że po okrzepnięciu Niemcy postawili Wielkopolanom twardy opór:

Motocykle, samochody staty rzędem [...] Sprzęt zdobyty - palono. Uruchomiliśmy jeden motocykl z przyczepką. Kiedy dołaczyłem do kompanii, zaraz przekazano [motocykl] w inne ręce. Radość trwała krótko. Wycofujemy się do wioski. Zajmujemy stanowiska z zadaniem powstrzymania pochodu wroga. [...] Uksztattowanie terenu to dolina, którą dzieli strumyk. Otrzymuję rozkaz okopania się i obrony skrzydła. Teren podmokty, torfiasty. Na gtębokości 1 1/2 topatki gromadzi się woda. Z boku grobla z przepustem strumyka zasłania całkowicie pole widzenia [...]. Po naszej stronie [na zachód od wsi] teren odkryty, niezabudowany. Po przeciwnej stronie zabudowania gospodarskie. Niemcy podjeżdzaja pojazdami, zasłonięci budynkami, pod sama wieś. Na sobie maja sprzęt bojowy, podwinięte rękawy, doskonale zamaskowani. [...] Zdaję sobie sprawę z zamiarów wroga. Opanować groble $i$ mieć pod ostrzałem prawie cała jednostkę. Samowolnie daję rozkaz do zajęcia stanowisk na grobli. Jesteśmy stale atakowani z czoła i skrzydła. Pociski z granatnika ląduja $w$ grzaskim torfie nie raniąc nikogo. Kończy się amunicja. Wysyłam ochotnika po amunicję. Niestety, wracając otrzymuje serię z karabinu

${ }^{31}$ W tym miejscu autora „Dziennika” wyraźnie poniosła wyobraźnia. Zarówno Polacy, jak i Niemcy rozpylali zasłonę ze świec dymnych, maskując swoje pozycje. Żadna ze stron pod Uniejowem nie użyła gazu. Gdyby polskie oddziały rzeczywiście użyły gazu bojowego, to ten fakt zostałby z pewnością wykorzystany przez aparat propagandowy III Rzeszy. Skoro się tak nie stało, to można mieć pewność, że sami Niemcy uznali tę uwagę za nieprawdopodobną.

${ }^{32}$ BArch, RH37/6582, Kriegstagebuch vom Polenfeldzug..., s. 27. 
maszynowego. Śmierć na miejscu, a tylko około 10 metrów brakowało do naszych pozycji. Porzuca stanowisko jeden z żotnierzy. Wyciagam rewolwer i nawoluje do powrotu. Nie zatrzymuje się. Nie dziwitem mu się. Przyniesiona amunicja w niewielkiej ilości wyczerpała się. Widocznie całej jednostce. Zapanowała złowroga cisza. Podrywa się następny żotnierz, a za nim pozostali towarzysze broni. [...] Po chwili cala jednostka wycofuje się. Po jakichś 200-300 metrach dowódca batalionu, mjr Edward Rukszan, rozkazuje: bagnet na broń i powrót na stanowiska. Podchodza do niego oficerowie. Zmiana rozkazu. Wycofać się do Uniejowa ${ }^{33}$.

Rozbity przeciwnik wycofał się na południe, tracąc co najmniej 60 zabitych i kilkunastu rannych. Straty polskie wyniosły 8 poległych i 11 rannych. Polacy zdobyli dużą ilość sprzętu, m.in. 12 samochodów, kilkadziesiąt motocykli, armatki przeciwpancerne. Część przejęto, doraźnie „motoryzując” własne pododdziały, resztę - z braku kierowców - na rozkaz dowódcy pułku podpalono. Dowódca 25 pal stwierdził wręcz, że zaroiło się od rowerów i motocykli, które byly używane dla utrzymania taczności $i^{34}$.

Saperzy stali się kompania zmotoryzowana po walkach 60 putku pod Uniejowem. Stato się to możliwe dzięki zdobytych na Niemcach samochodom. Zaskoczony byłem, gdy widziałem pierwszy, czarny wóz niemiecki z tabliczka WH, a w nim polskich saperów w skórzanych kurtkach, czarnych beretach na głowie. Takich wozów byto więcej, tylko, że dużo spalono - wspominał jeden z żołnierzy $29 \mathrm{pp}^{35}$.

W Balinie zapłonął „las pochodni”, będący dla Wielkopolan symbolem tak wyczekiwanego triumfu i działający mobilizująco na żołnierzy, dla Niemców zaś był to sygnał ostrzegawczy, że Polacy stoją na straży Uniejowa.

Ciekawych informacji dostarcza dziennik bojowy, tym razem innego oddziału 30 DP - batalionu saperów, choć zdaje się, że są to już wiadomości „z drugiej ręki”:

Grupa Adelhoch poniosta szczególnie w szwadronie zwiadowczym $i$ kompanii kolarzy bardzo ciężkie straty. Na przyklad zmotoryzowany

${ }^{33}$ T. Pacanowski, Pierwszy poważny kontakt mego uczestnictwa $w$ działaniach wojennych 1939 roku (fragment), [w:] Z. Jagodziński, 60 Pułk Piechoty Wielkopolskiej, Ostrów Wielkopolski 2016, s. 116-117.

${ }^{34}$ A. Wojtanowicz, Wspomnienia artylerzysty. O działaniach bojowych 25 pal ziemi kaliskiej w kampanii wrześniowej 1939 roku, „Ziemia Łęczycka” 1960, nr 10, s. 7. O braku kierowców wspomina ppor. Gabriel Wierzbicki, PISM, B.I.37D, Relacja ppor. G. Wierzbickiego, k. 17. Literacki opis boju pod Balinem sporządził J. Korczak, dz. cyt., s. 115-121.

${ }^{35}$ T. Pietrzak, Wrześniowe dni, opr. J. Pereświet Sołtan, Turek-Kalisz 2005, s. 102. 
szwadron zwiadowczy wpadt z tego powodu w zasadzkę, że na wjeździe do wsi zostat umiejscowiony szyld z napisem „,Tutaj oddziaty niemieckie, nie strzelać”. Podczas przejazdu nastapit silny atak, który wyłaczyt $z$ walki większa część kübelwagenów ${ }^{36}$ wraz z przyczepionymi do nich działami i karabinami maszynowymi ${ }^{37}$.

W sztabie niemieckiej 30 DP sytuację, powstałą po starciu w Balinie, uznano za ,poważną”, tym bardziej, że w ręce polskie wpadła także mapa z zaznaczonymi kierunkami działań niemieckich WJ, warta więcej niż dziesięć meldunków lotniczych ${ }^{38}$.

W środę 6 września, przy nieprzerwanie sprzyjającej pogodzie (bezchmurne niebo i wspaniała widoczność), niemieckie lotnictwo kontynuowało ciężkie naloty, próbując zbombardować zarówno kolumny wojska, jak i cele cywilne. Potężna fala ataków powietrznych miała miejsce po południu. Tym razem samoloty Luftwaffe zostały zaatakowane przez polskich myśliwców z Brygady Pościgowej (płk pil. Stefan Pawlikowski, dowódca 1 Pułku Lotniczego). Jeden Heinkel He 111 z działających wówczas wspólnie 4 i sztabowej eskadry 2 dywizjonu 26 pułku bombowego (Stabsstaffel i Staffel 4 II/KG 26) został między godz. 15.10 a 15.30 strącony nad Uniejowem. Zniszczonego Heinkla pilotował albo plut. Hermann Nolting, albo plut. Karl Detlefsen, bowiem śmierć członków załóg tych pilotów potwierdzają źródła niemieckie (drugi z bombowców spadł

${ }^{36}$ Najprawdopodobniej chodzi o samochody Volkswagen Typ 62, które w niewielkiej ilości, jako jednostki prototypowe, zostały użyte do testów bojowych we wrześniu 1939 roku. Zebrane w ten sposób doświadczenia pomogły w konstrukcji klasycznego kübelwagena armii niemieckiej - Volkswagen Typ 82, który wszedł do produkcji w 1940 roku.

${ }^{37}$ Rosyjsko-niemiecki projekt „Dokumenty niemieckie w Rosji”, „Einsatz des Pi. Btl. 30 in Polen" [http://wwii.germandocsinrussia.org]. Ostatnia z przytoczonych niemieckich relacji jawi się szczególnie interesująco, gdyż stanowi próbę odpowiedzi na pytanie o przyczyny niefrasobliwości czołowych pododdziałów niemieckich, które wpadły w zasadzkę pod Balinem. Jeśli przyjąć, że rzeczywiście dowódca polski, ppłk. M. Frydrych lub jeden z jego podwładnych, wpadł na pomysł umieszczenia tablicy informacyjnej w języku niemieckim, że teren jest już pod kontrolą oddziałów niemieckich, to taki element dezinformacji przeciwnika, należałoby ocenić bardzo wysoko, jako genialny w swej prostocie i przede wszystkim skuteczny. Niestety, żadne źródła polskie tego nie potwierdzają. Sytuację uprawdopodabnia fakt, że 6 września o godzinie 10.00 sztab 30 DP Wehrmachtu wyraźnie ostrzegł dowództwo 6 batalionu km, że sąsiadująca 24 DP Wehrmachtu atakuje w kierunku północnym i należy zwrócić szczególną uwagę, by nie ostrzelać własnych oddziałów. Nie można też wykluczyć, że niefrasobliwość Niemców spowodowana była zmęczeniem marszem przy upalnej pogodzie, a wspomnienie o ustawionych jakoby przez Polaków tablicach było tylko wymówką. Ostrzeżenie ze sztabu 30 DP: BArch, RH26-30/1, Kriegstagebuch nr 1..., s. 29.

${ }^{38}$ K. Szepietowski, dz. cyt., s. 119; W. Rezmer, dz. cyt., s. 170-171; K. Kuźmiński, dz. cyt., s. 189. Mapę znaleziono w aktówce poległego oficera. O zdobytej mapie zob. PSZ, s. 530; P. Bauer, B. Polak, dz.cyt, s. 174; A. Zawilski, dz. cyt., s. 15. 
w rejonie Koło - Łęczyca ${ }^{39}$. Zwycięskimi myśliwcami byli piloci ze 113 eskadry myśliwskiej 4 dywizjonu 1 Pułku Lotniczego w Warszawie ${ }^{40}$.

Nocą z 6 na 7 września uniejowski rynek był pełen polskich żołnierzy z oddziału ppłk. M. Frydrycha. Zwycięski bój 2 batalionu znakomicie podniósł morale, nadwyrężone marszami bez kontaktu bojowego z nieprzyjacielem. Uwagę Polaków zwracały leżące w narożniku rynku ciała poległych kilka godzin wcześniej lotników niemieckich z załogi Heinkla, „młodych, wysokich blondynów, dobrze umundurowanych". Kilku ciężko rannych Niemców zmarło w prowizorycznym punkcie sanitarnym w budynku szkoły ${ }^{41}$.

\section{DRUGA FAZA WALK. KONTRATAK NIEMIECKI 7 WRZEŚNIA NAD RANEM}

Tej samej nocy po stronie niemieckiej nastąpiło przegrupowanie. Rozdrażnieni rozmiarami klęski Grupy „Adelhoch” w pierwszym poważnym boju dywizji, Niemcy rozpoczęli przygotowania do ataku na Uniejów, w celu wyparcia znajdujących się tam sił polskich i zdobycia miasta. O godzinie 2.30, na pomoc 6 batalionowi km w okolice Balina został skierowany 46 pułk piechoty (gen. mjr W. Wittke). OR 30 DP został przesunięty bardziej na wschód, o godzinie 2.30 meldował swoje najbardziej na wschód wysunięte położenie we wsi Szarów Księży, $5 \mathrm{~km}$ na południowy wschód od Uniejowa i $4 \mathrm{~km}$ od miejsca boju sprzed kilku godzin. W tym samym czasie sąsiednia 24 DP była w Poddębicach, a jej OR, wraz z częścią 31 pp, w Wartkowicach. Zgodnie z rozkazami dowódcy armii, dywizja ta podążała w szybkim tempie w kierunku Warszawy.

W wyniku przegrupowania, naprzeciw pozycji OW ppłk. M. Frydrycha stanęły znacząco większe siły niemieckie. Przeciwników dzieliła niewielka odległość, liczona co najwyżej w setkach metrów ${ }^{42}$. Zadania dla osamotnionego polskiego OW nakazywały utrzymać przeprawę do godzin popołudniowych, przy czym trudno było oczekiwać na poważne wsparcie ze strony WJ armii „Poznań”, kierowanych szybkim marszem w rejon Łęczycy. Sytuacja Polaków była więc bardzo trudna, ustępowali bowiem Niemcom pod względem liczebności, wyposażenia, posiłków, wsparcia artyleryjskiego i lotniczego.

${ }^{39}$ M. Emmerling, dz. cyt., cz. II, s. 122. Autor, polegając jedynie na źródłach niemieckich, zbyt ogólnie określił miejsce walki jako rejon Łęczycy.

40 J.B. Cynk, Polskie Lotnictwo Myśliwskie w boju wrześniowym, Gdańsk 2000, s. 273; M. Emmerling, dz. cyt., cz. I, s. 93-94 i 96; cz. II, s. 149.

${ }^{41}$ K. Kuźmiński, dz. cyt., s. 188-189. O leżących na rynku ciałach poległych lotników niemieckich wspominali także por. Tadeusz Sznajder z 29 pp: PISM, B.I.37B, Relacja por. rez. T. Sznajdera, k. 13 oraz ppor. rez. art. Józef Ostrowski z 25 pal: PISM, B.I.37F, Relacja ppor. rez. art. J. Ostrowskiego, k. 23.

${ }^{42}$ PISM, B.I.37D, Relacja por. A. Okunińskiego, k. 14. 
Podpułkownik M. Frydrych, świadom tych trudności, późnym wieczorem poprzedniego dnia posłał swojego I adiutanta, kpt. Kazimierza Szepietowskiego

w celu osobistego przekazania rozkazów: 1 baon zostaje skierowany na Józefów, Szarów Księży i Szarów Pański, gdzie ubezpiecza się na noc placówkami bojowymi. 2 baon ma się przegrupować, zabezpieczyć ogniem szosę $i$ drogi na południe $i$ wschód. W obu baonach należy wyznaczyć na ubezpieczenie niezbędna liczbę żotnierzy, reszta winna wypoczywać [...] Okoto pótnocy przybyt do Uniejowa 3 baon, wracając do składu pułku. Po przeszło czterdziestokilometrowym marszu, odbytym z Galewa, wymagat koniecznie wypoczynku. Baon odchodzi więc do odwodu putku w Ubystawiu i Woli Przedmiejskiej. Jesteśmy znów w komplecie $i$ w dobrym nastroju po dzisiejszym sukcesie ${ }^{43}$.

Jadąc motocyklem pomiędzy oddziałami pułku, adiutant dowódcy 60 pp bacznie obserwował sytuację i nastroje Wielkopolan:

$\mathrm{Na}$ szosie $w$ Balinie zastaje las pochodni. Nie orientuje się początkowo, co to znaczy, gdyż dowódca pułku wspominat mi tylko mimochodem, że za dzisiejsza akcję spodziewa się wysokiego odznaczenia. Pality się pojazdy niemieckie. [...] Noc jest, jak codziennie dotychczas od wymarszu z Ostrowa, bardzo chłodna. Nie można też dziwić się żotnierzom, że nie bardzo respektuja nawolywania dowódców do okopywania się i kręca się w pobliżu płomieni, choć artyleria niemiecka posyła od czasu do czasu serię pocisków do wyraźnego celu, jakim sa płonace pojazdy. Pierwsze wyraźne zwycięstwo nad przeciwnikiem, przed którym dotychczas się uchodziło, wywiera odpowiedni wplyw na żotnierzy. Widać to wyraźnie po twarzach rozmawiających ze mna szeregowców $i$ ich lekceważacym zachowaniu $w$ stosunku do ognia artylerii nieprzyjacielskiej ${ }^{44}$.

Wysunięty na pozycje pod Balinem 2 batalion 60 pp mjr. E. Rukszana nad ranem nadal nie był w pełni zorganizowany.

Kwadrans po wschodzie słońca, o godz. 5.15, OR 30 DP zaatakował z Kolonii Józefów w kierunku północno-wschodnim, napotykając stanowiska polskiego 1 batalionu mjr. Aleksandra Fiszera. Półtorej godziny później, o 6.45, 6 batalion km meldował, że został zaatakowany przez piechotę wzmocnioną batalionem zmotoryzowanym, pozostając samotnie w ciężkich walkach defensywnych na polach wsi

$43 \quad$ K. Szepietowski, dz. cyt., s. 120.

44 Tamże, s. 120. 
Dominikowice, na południe od Kolonii Balin. W porannej mgle walki trwały w tym rejonie od ponad godziny. W niemieckim meldunku stanowczo wyolbrzymiono polskie siły, bowiem w kierunku Dominikowic wysunęła się jedynie 4 kompania kpt. J. Zwolaka. Niemcom udało się Polaków odrzucić, a następnie wyprzeć z Balina 5 kompanię. Obie polskie kompanie w ogniu przeciwnika cofnęły się na pozycje odwodowej 6 kompanii, po czym skrwawiona 4 kompania przeszła do odwodu.

Poranny chłód i silne zamglenie nie sprzyjały walczącym żołnierzom. Jako pierwsi przekonali się o tym Niemcy. Wkrótce po rozpoczęciu walk OR 30 DP meldował o swojej pozycji na południowym skraju i ok. $1 \mathrm{~km}$ na południowy wschód od wsi Niewiesz. OR musiał się wycofać, gdyż został ostrzelany przez własnych sąsiadów. Jego dowódca, mjr Lindheim, zażądał danych o położeniu własnych oddziałów. O godzinie 7.15 dowódca dywizji, gen. K. von Briesen wydał $46 \mathrm{pp}$ rozkaz przesunięcia głównego kierunku ataku w prawo, a zatem na pozycje bronione przez polski 1 batalion mjr. A. Fiszera. Batalion rezerwowy $46 \mathrm{pp}$ pułku miał przesunąć się ok. $2 \mathrm{~km}$ na południe od Niewiesza w celu wsparcia OR, a następnie działać pomiędzy zachodnim skrajem Niewiesza a wschodnim przedpolem Uniejowa przez „niczyją” wieś Boczki. W późniejszym rozwoju walki gen. K. von Briesen przewidywał udział wzmocnionego 6 pp, mającego oskrzydlić Uniejów od wschodu (zob. ryc. 2).

O godzinie 7.40 OR zameldował o wycofaniu się z powodu ciężkiego ostrzału artyleryjskiego, po raz kolejny także prosił o dane, gdzie znajdują się pozostałe oddziały dywizji. Najcięższe konsekwencje porannego chaosu poniosła kompania kolarzy OR 30 DP. Niemieccy rowerzyści wjechali wprost pod lufy żołnierzy polskiej 3 kompanii 60 pp (kpt. Bolesław Majewski). Ogień maszynowy zdziesiątkował Niemców, którzy porzuciwszy rowery, próbowali szturmować pozycje 3 kompanii. Niemcy stracili tam około 80 poległych, samochód, kilka motocykli i kilkadziesiąt rowerów ${ }^{45}$. O godz. 9.15 rozpoczął się połączony atak dwu batalionów 46 pp - 1 (mjr Coep) i 3 (mjr G. Weichardt), wraz z 6 batalionem km. Ostatni - 2 batalion (ppłk. Nolte) 46 pp wiązać miał ogniem po obu stronach drogi Dominikowice - Uniejów 2 batalion 60 pp.

Działania polskich oddziałów miały być w znacznej mierze improwizowane.

Zadania dla batalionu na 7 września: za wszelka cenę powstrzymać posuwającego się naprzód nieprzyjaciela. Rozkazy bojowe: żadne, wiadomości o ogólnym położeniu, o nieprzyjacielu, o sąsiadach żadne - podsumował ppor. Stanisław Pawlaczyk, dowódca plutonu moździerzy z 3 kompanii km 3 batalionu $60 \mathrm{pp}^{46}$.

\footnotetext{
45 Tamże, s. 121.

${ }^{46}$ PISM, B.I.37D, Relacja ppor. S. Pawlaczyka, k. 53.
} 


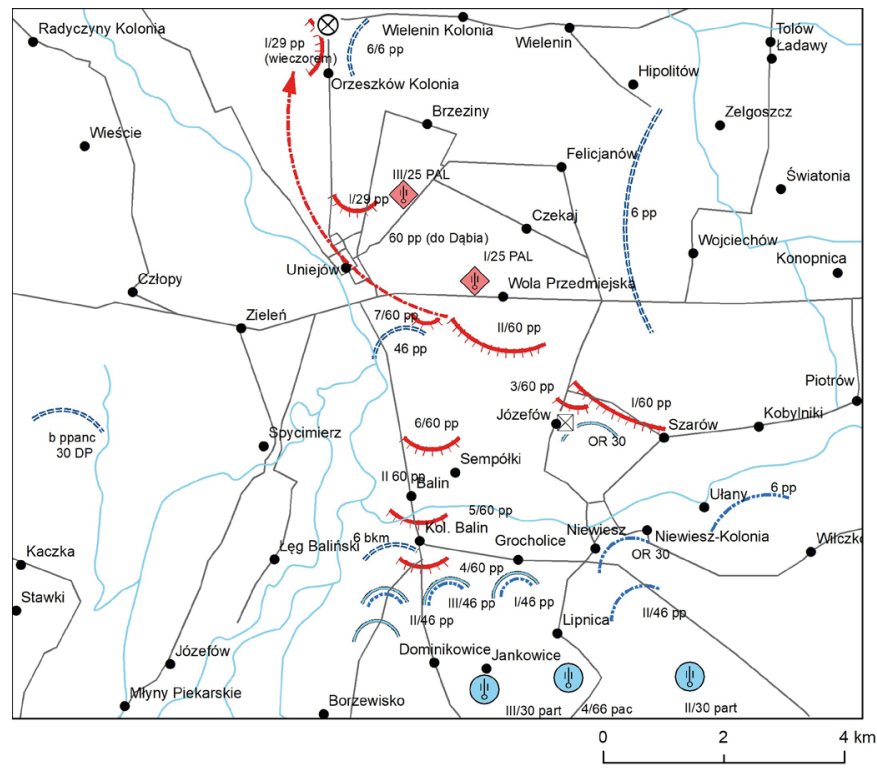

\section{Objaśnienia}

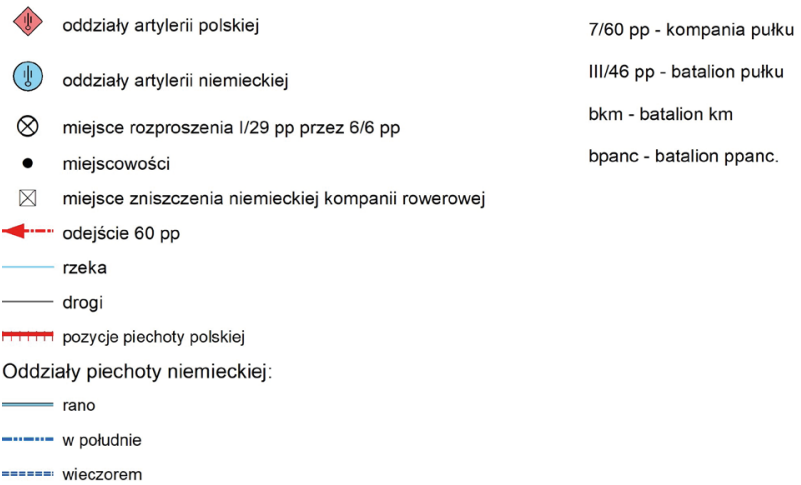

Ryc. 2. Kontratak oddziałów niemieckiej 30 DP pod Uniejowem 7 września Źródło: opracowanie własne

Zamieszanie pierwszych godzin walki nie ominęło także Polaków. Część odwodowego 3 batalionu 60 pp (mjr Jan Zgrzebnicki), który przybył do Uniejowa minionej nocy, zabłądziła i zamiast zająć stanowiska w folwarku Ubysław na południowy-wschód od Uniejowa, blisko Józefowa, maszerowała na północ w kierunku Dąbia. Powrót zapchaną szosą był znacznie spowolniony. Ostatecznie jednak batalion zdołał wesprzeć 2 batalion walczący pod Balinem. Kapitan Kazimierz Kuźmiński, dowódca 7 kompanii 60 pp, we wspomnieniach spisanych w 1946 r., wskazał wiele szczegółów tych dramatycznych godzin: 
Jest jeszcze ciemno, czekamy na rozkazy. Wreszcie wraca dowódca [3 batalionu], z zadaniem dla batalionu. Nasz batalion ma przesunąc się do dworu Ubystaw i trzymać tę miejscowość tak dtugo, dopóki cały pułk nie odejdzie ze swych stanowisk po przejściu Dywizji przez Uniejów. Idziemy na czele z ppor. Serbińskim ${ }^{47}$ i omawiamy ostatnie zdarzenia. Nastrój jest dobry, ostatnie sukcesy przyczynity się do tego. Zaczyna sięrozwidniać, ale idziemy dość dlugo i Ubystawia nie widać, wyciagam mapę, orientuję się $i$ widzę, że jesteśmy na szosie do Dąbia. [...] Tymczasem z prawej strony ze wschodu stychać silnq i bliska walkę. Czuje się zaniepokojony niejasna sytuacja $i$ wysytam kaprala-obserwatora na rowerze na czoło do dowódcy batalionu, aby dowiedziat się o zmianie rozkazu. Po kilku minutach wystany wraca i melduje mi, że dowódcy batalionu na szosie nie ma $i$ że 9 i 8 kompanii też nie ma, a tylko część taboru i nasza kompania maszeruje po szosie. Ktoś tu zawinit, a tymczasem nasze dwie kompanie już walcza pod Ubystawiem bez nas. Co za wstyd! Musimy zawracać $i$ to szybko. Latwiej to przewidzieć niż zrobić - bo oto od Uniejowa wali kolumna za kolumna, szosa zapchana i pod prąd ciężko się przeciskać. Mijamy z mozolem, maszerujemy troche polem, trochę szosa. [...] Dochodzimy do dworu Ubystaw, zatrzymuje kompanię za sklonem $w$ szykach luźnych, a sam $z$ obserwatorem i gońcami ide do dowódcy batalionu. Tu już jest goraco. Trzeba co chwile padać i robić skok, jesteśmy już w ogniu artylerii i niemieckich cekaemów. Granat celnie strzelony zapala stodołe dworska, która w ułamku sekundy staje w ptomieniach jak pochodnia. Wybuchy granatów, suchy, przykry trzask cekaemów, jęki rannych, krzyki komend $i$ rozkazów, wszystko to razem tworzy ogłuszajaca kakofonię. Zaciszne zakamarki dworskie między budynkami, dajace jako taka ochrone, sq wykorzystane to na telefoniczna tacznice batalionowa, to na punkt opatrunkowy, to na punkt dowodzenia. Dostaję się do dowódcy batalionu [...]. Dostaję zadanie: mam ubezpieczyć zbyt odstonięte lewe skrzydto batalionu. Zajmujemy stanowiska, okopujemy się, ogień cekaemów nie dochodzi do nas, ale sięga nas artyleria. Na szczęście poza lekko rannymi ofiar nie ma. Z tylu co pewien czas strzela ponad naszymi głowami nasz pluton artylerii por. Hnatyka ${ }^{48}$, jeszcze więcej z tyłu

${ }^{47}$ Ppor. Dominik Serbiński, dowódca 1 plutonu 7 kompanii 60 pp. W relacji tego właśnie oficera (PISM, B.I.37D, Relacja ppor. D. Serbińskiego, k. 40) znajduje się informacja warta odnotowania: żołnierze z 3 batalionu byli tak zmęczeni, że jeszcze około 9 rano, pod ogniem nieprzyjaciela, spali na pozycjach bojowych.

${ }^{48}$ Por. Jerzy Hnatyk, dowódca plutonu artylerii piechoty $60 \mathrm{pp}$. 
bateriapolówekwspierającanaszbatalion. Niemcyzalegliprzedpole $w$ odległości czterystu metrów od naszej pierwszej linii i nie ida naprzód. Nasze cekaemy wzbudzaja respekt $i$, jak potem nieraz mamy okazje sprawdzić, sa skuteczne. Do pierwszej linii zajeżdza autem dowódca putku. Wychodzi z samochodu i staje wyprostowany $w$ tym piekielnym ogniu. Imponujaco to wyglada - mam dla niego najwyższy podziw za te pogardę śmierci, na jaka zdobywa się ten stary żolnierz ${ }^{49}$. [...] Po pewnym czasie dowódca pułku dochodzi do mnie i daje mi rozkaz, abym z tymi dwoma plutonami, które mam przy sobie, szedt na pomoc dowódcy 2 batalionu do miejscowości Balin. Chcę dojść do Balina po skłonie stoku, na którym się znajdujemy, aby ostonić mych żotnierzy przed ogniem niemieckich cekaemów. Ки mojemu i dowódcy batalionu zdumieniu dowódca putku każe mi iść pod ogniem niemieckim, równolegle do frontu, do naszej pierwszej linii. Wykonuję ten rozkaz. Uniesiony ambicja idę z 1 plutonem na najwięcej ostrzelanym miejscu, aby dać przykład swym żotnierzom. Dochodzimy do pierwszej linii 2 batalionu. Rzeczywiście, pomoc tu bardzo potrzebna, bo z 2 batalionu niewiele zostato. Ta reszta osobiście dowodzi mjr Rukszan. Jesteśmy pod bardzo silnym ogniem doskonale zamaskowanych niemieckich cekaemów. Szczególnie jeden jest uprzykrzony, nie pozwoli nam się rozwinać i ruszyć. Staramy się wraz z dowódca sekcji granatników, kpr. Florczakiem, ustalić miejsce, z którego ten ckm strzela. Każę mu postać pare granatów $w$ przypuszczalny rejon i rzeczywiście po naszej serii cekaem umilkt. Niemcy bardzo ostrożnie i powoli posuwaja się naprzód, wspierani potężnym ogniem cekaemów $i$ artylerii. Odgryzamy się jak możemy i wolniutko wycofujemy się. [...] Robi się coraz goręcej. Wieś pali się, smaża się żywcem psy, krowy $i$ świnie, wszystko to ryczy $i$ wyje. Na drodze biegnacej przez wieś szkielety popalonych samochodów i motocykli niemieckich, obok nich trupy Niemców - to po wczorajszym zwycięstwie. Mam okropne pragnienie, biore od trupa niemieckiego motocyklisty, jakby śpiacego w przyczepce, jego manierke, napetniam woda ze studni i sokiem z okna jakiejś chatupy. Naokoło piekielna serenada, salwy artyleryjskie, serie cekaemów, trzask ognia $i$ walacych się domów, ryki zwierząt. Nasza słaba linia trzyma w szachu Niemców, którzy napieraja coraz silniej ${ }^{50}$.

${ }^{49}$ Podpułkownik Marian Frydrych, dowódca 60 pp, poległ w wieku 42 lat śmiercią żołnierską 11 dni później, 18 września, w Dąbrowie Starej, próbując zebrać rozproszone w Puszczy Kampinoskiej oddziały pułku.

${ }^{50}$ K. Kuźmiński, dz. cyt., s. 189-191. 
Silny opór polskich batalionów 60 pp zatrzymał Niemców. 6 batalion km musiał się cofnąć i liczyć na odsiecz oddziału mjr. G. Weichardta. 2 batalion 46 pp został przesunięty na niemieckie prawe skrzydło - północny skraj lasu, skąd wyprowadził atak w kierunku Niewiesza, na pozycje 1 batalionu $60 \mathrm{pp}$. W rosnącym zamieszaniu Niemcy utracili łączność z OR. W tym samym czasie czołowy batalion 6 pp (płk J. Reichert) osiągnął wieś Krępa i znalazł się w celnym ogniu polskiej artylerii. Poległ m.in. kpt. Tiedmann, dowódca 5 kompanii 6 pp, a ranny został dowódca plutonu 6 kompanii ppor. von Blomberg.

Cytowany już anonimowy żołnierz 3 kompanii 6 batalionu karabinów maszynowych tak kilka miesięcy później referował poranną fazę bitwy:

Nadchodza positki. Nad ranem kompania zostaje na nowo uformowana i wspólnie z 46 pp przeprowadzamy atak na szerokim froncie. Także 7 września Polacy sprawiaja nam sporo trudności $i$ na lewym skrzydle atak zamiera, przez otwarty teren nie sposób przejść. Ale nasza piechota na prawym skrzydle trzyma się dzielnie, nawet sprawiła, że przeciwnik nieco się cofnąt. Lewe skrzydto leży przy rowie z woda porośniętym zaroślami olchowymi. Przedarcie się do przodu jest niemożliwe, otrzymujemy bardzo dobrze wycelowany ogień. Towarzysz, który nieco się podnióst, by lepiej widzieć, pada ciężko ranny. Polacy na nowo zaatakowali na prawym skrzydle i siedza już na naszej prawej flance. Możemy tylko ustapić na lewo, by nie zostać calkiem odcięci i po jakimś czasie, droga naokoło, osiagamy nasze oddziały tytowe ${ }^{51}$.

Inny niemiecki uczestnik tych walk, żołnierz przysłanej na pomoc 3 kompanii 46 pp, wspominał:

Czwartek 7.09.1939. Moja 3 kompania zostaje użyta między 6 batalionem $\mathrm{km}$ a 10 kompaniq naszego putku. Dalej następuje atak zgodnie ze schematem wtloczonym nam przed wojna: ostrzat - ruch. Osiagamy boczna droge, po której pędza wozy amunicyjne 6 batalionu karabinów maszynowych, by pokryć zapotrzebowanie naszych karabinów maszynowych. Najdalej wysunięta na lewo jest czwarta grupa. Udaje jej się przez niezbyt porośnięty teren dotrzeć do rzędu topoli. Reszta kompanii wisi jeszcze trochę z tylu, ale $w$ wyniku żywego zagrzewania do boju przez szefa kompanii także i ta reszta dołacza do przodu. Przybywajacy ze wszystkich kierunków ostrzat spowodowat pierwsze ofiary wśród nas. Wszędzie

${ }^{51}$ BArch, RH37/6582, Kriegstagebuch vom Polenfeldzug..., s. 27. 
rozlegaja się krzyki o sanitariusza. Co jakiś czas odkrywamy strzelca z krzaków ${ }^{52}$.

O determinacji Niemców świadczyć może fakt, że do walki w pierwszej linii wysłali także oddziały dywizyjne, zazwyczaj rzadko używane w takich sytuacjach, jak batalion saperów. W „Dzienniku bojowym” tego oddziału 30 DP zapisano pod datą 7 września:

1 kompania $^{53}$ użyta jest pod Kol. Balin jako piechota (w ramach 46 putku piechoty). Jeden pluton jest z przodu, dwa plutony zostaja użyte na tyłach do oczyszczania zagród i lasów ze strzelców ukrytych na dachach i drzewach. Ta walka z tylu frontu była szczególnie nieprzyjemna. Przed ukrytymi w stogach $i$ na drzewach, po części za ostonami pancernymi Polakami można byto się tylko obronić, jeśli wszystko, co tylko dawało możliwość ukrycia się, zostato podpalone. A także $i$ wtedy ci wytrzymali Polacy strzelali jeszcze $z$ palacych się domów. $W$ ten sposób, w nocy z 6 na 7 września widziało się wokót aż po horyzont palace się zagrody i stogi $i^{54}$.

W miarę upływu kolejnych godzin Niemcy zaczęli zyskiwać przewagę. Jak skrzętnie odnotowano w dywizyjnym dzienniku bojowym, o godzinie 10.45 3 dywizjon (mjr Faber) 30 part rozpoczął ostrzał Uniejowa, natomiast 2 dywizjon (mjr Albrecht Wüstenhagen) tego samego pułku skierował swój ostrzał na wycofujące się drogą w kierunku Dąbia oddziały polskie. O godzinie 11.00 „odnalazł się” OR 30 DP i zameldował o ponownym zdobyciu wsi Niewiesz i wyparciu stamtąd polskiego 1 batalionu. Na szczeblu dywizyjnym podjęto też decyzję o wdrożeniu wcześniejszych planów użycia 6 pp do działań oskrzydlających Uniejów od wschodu i pościgu na linii Krępa - Niewiesz - Biernacice - Wielenin. Wyjaśniła się też przyczyna braku łączności z OR. Dowodzący nim mjr Lindheim ściśle wypełniał rozkaz, by wstrzymać kontakt radiowy. O godzinie 11.354 bateria (kpt. Haberbosch) 66 pac (mjr Gustav Hundt) rozpoczęła z okolic Lipnicy ostrzał Uniejowa. O godzinie 13.40 nadszedł meldunek od 6 batalionu km, że osłania on lewą flankę 46 pp, lecz nie może posunąć się do przodu. Straty własne batalionu $\mathrm{z}$ tego dnia to 1 poległy oficer, 2 ciężko rannych, oraz 40 żołnierzy i podoficerów.

${ }^{52}$ Geschichte des Infanterie - Regiments 46 1. Oktober 1934 bis 8 Mai 1945, Teil II, Kameradschaft 1988, s. 5.

${ }^{53}$ Dowódcą kompanii był mjr Wegener, dowódcy plutonów: ppor. Kalbitz, ppor. Kaiser, sierż. Hütwohl. Nazwiska i stopnie na podstawie http://gliederungundstellenbesetzung.blogspot. com/2011/12/pionier-bataillon-30.html. [dostęp: 12.03.2020].

54 Rosyjsko-niemiecki projekt „Dokumenty niemieckie w Rosji”, Einsatz des Pi.Btl. 30 in Polen, http://www.germandocsinrussia.org. 
Silny ogień z broni maszynowej przy wsparciu artylerii zadał Polakom poważne straty: w czasie walki o Uniejów po raz pierwszy zauważylem przygniatająca przewagę niemieckiej artylerii - wspominał dowódca 7 kompanii $60 \mathrm{pp}^{55}$. Wiele pracy miały służby medyczne 60 pułku, punkty opatrunkowe tworzono na skrzyżowaniach dróg, ponieważ zabudowania były pod silnym ogniem. Najciężej rannych odesłano samochodami aż do Kutna, gdzie znajdował się szpital ${ }^{56}$. Nieco lepiej wyglądała sytuacja 1 batalionu 60 pp, który po sukcesie pod Józefowem zajął rejon wsi Niewiesz - Ułany. Żołnierze mjr. A. Fiszera musieli jednak stamtąd ustąpić pod naciskiem niemieckiego OR. Ze stanowisk polskich widać było, że Niemcy podprowadzają nowe siły, m.in. na pole bitwy zdążał $6 \mathrm{pp}$, wsparty artylerią. Podpułkownik M. Frydrych obawiał się nawet oskrzydlenia swojego oddziału, ale wysłani zwiadowcy nie potwierdzili tego przypuszczenia.

W międzyczasie zrobiło się poludnie. Upał leje się z nieba. Kompania zostaje na nowo zorganizowana, pierwsze doświadczenia zostaja ocenione. Teren zostaje teraz planowo przeszukany, byżaden strzelec z krzaków nam nie zbiegt. Do późnych godzin popołudniowych zbliżliśmy się na ok. 1,5 km do Uniejowa. Otrzymaliśmy rozkaz, by okopać się na noc. Wyszukujemy sprzyjajacego miejsca, na prawo 1 pluton, obokz lewej 2 pluton i oparty o droge 3 pluton-wspominał żołnierz 3 kompanii $46 \mathrm{pp}^{57}$.

Z kolei Josef Walzel, inny żołnierz tego samego 1 batalionu 46 pp, w swoim dzienniku zanotował pod datą 7 września:

O godzinie 6.30 przygotowat sie nasz pułk do natarcia przeciwko podwójnie silniejszemu przeciwnikowi. Nasza kompania jako odwód pułkowy. Byta to pierwsza, lecz bardzo ciężka walka. Najgorsi byli polscy strzelcy strzelający z drzew. Myśmy mieli dosyć strat $i$ nie mogliśmy początkowo wsi brać, gdyż polska artyleria się jeszcze na nas wstrzeliwała. Poparci przez ogień ciężkiej artylerii, przez nas ostanianej, zajęliśmy wieś o godzinie 15.00 po południu i podpaliliśmy wszystkie domy. Dużo partyzantów także zastrzeliliśsmy (3 kompania 2 zabitych, kilku ciężko rannych, 1 lekko ranny). Przenocowaliśmy $w$ gotym polu, a noc uptynęta względnie spokojnie ${ }^{58}$.

${ }_{55}^{5 I S M, ~ B . I .37 D, ~ R e l a c j a ~ k p t . ~ K a z i m i e r z a ~ K u z ̇ m i n ́ s k i e g o, ~ k . ~} 36$.

${ }^{56}$ PISM, B.I.37D, Relacja ppor. lek. M. Natkańskiego, k. 5.

${ }^{57}$ Geschichte des Infanterie - Regiments 46..., s. 5.

${ }^{58} \mathrm{CAW}$, II.13.14, Odpis dziennika Józefa Walzela dokonany i przetłumaczony przez oficera wywiadu 25 DP kpt. Jewasińskiego. 
Kadrę dowódczą pododdziałów pułków piechoty 30 DP stanowili weterani I wojny światowej, którzy w czasie zaciekłych starć nie ulegali panice i potrafili poderwać podwładnych do walki ${ }^{59}$.

Silny i celny ogień Polaków był dla żołnierzy Wehrmachtu dużym zaskoczeniem. Twierdzili potem, że polskim pododdziałom towarzyszyli uzbrojeni cywile, nie tylko strzelający, ale i kierujący ogniem ${ }^{60}$. Analogicznie polscy oficerowie obawiali się dywersji ze strony Niemców - kolonistów ${ }^{61}$.

Pod osłoną $60 \mathrm{pp}$, nad ranem 7 września, przez Uniejów przeszły dwie kolumny Wielkopolskiej Brygady Kawalerii gen. bryg. Romana Abrahama, wykonujące rozkaz przemarszu z Turku w rejon Dąbia n. Nerem ${ }^{62}$. Jadąc kłusem ułani minęli ok. godz. 6.00 szykujący się do przejścia przez most 56 pp z 25 DP (płk Wojciech Tyczyński). Warunki przeprawy były ciężkie, trwały bowiem ostrzał artyleryjski i bombardowanie z powietrza ${ }^{63}$. Wachmistrz Edmund Tomiak z Wielkopolskiej BK później wspominał:

$W$ Uniejowie zobaczytem prawdziwa wojne, a właściwie jej tragiczne skutki. Przede wszystkim wielką masę ludzi-uciekinierów, ciagnacych wraz z dobytkiem żywym i martwym szosami i drogami na wschód. I mase wojska - żotnierzy różnych rodzajów broni i jednostek, rozbitków, zagubionych, bez dowódców. Panowat tam rozgardiasz, w którym łatwo byto zginać. Zgietk, huk rozrywajacych się bomb zrzucanych przez niemieckie lotnictwo, pisk ranionych koni i płacz tysięcy ludzi, bezbronnych pod polskim niebem ${ }^{64}$.

Bohaterska postawa żołnierzy 25 baterii artylerii plot. (kpt. P. Żniński) oraz samodzielnej kompanii ckm nr 73 sprawiła jednak, że ostrzał z broni pokładowej

${ }^{59}$ PISM, B.I.37C, W. Tyczyński, Sprawozdanie z udziału w kompanii polskiej 1939, s. 7.

${ }^{60}$ H. Breihaupt, Die Geschichte der 30. Infanterie Division 1939-1945, Bad Nauheim, 1955, s. 18. Niemcy bezpodstawnie podejrzewali mieszkańców wsi o pomoc polskim żołnierzom. Zjawisko to zyskało w historiografii niemieckiej określenie „partyzanckie urojenia”. Zob. J. Böhler, Zbrodnie Wehrmachtu w Polsce. Wrzesień 1939. Wojna totalna, Kraków 2009, s. 22 i n. Maszerujące przez Polskę oddziały Wehrmachtu były przeświadczone, że walczą nie tylko z regularnymi oddziałami armii polskiej, ale także partyzantką, do której należą licznie polska ludność cywilna. W pierwszych dniach września w wielu miejscach dochodziło do wywołanej nerwowością niedoświadczonych rekrutów wymiany ognia, za którą Niemcy obarczali odpowiedzialnością i karali miejscową ludność. Taka sytuacja miała też miejsce na terenie gminy Uniejów, m.in. we wsi Czekaj, czy w samym mieście; T. Wójcik, Skrwawione..., s. 56.

${ }^{61}$ K. Szepietowski, dz. cyt., s. 122

${ }^{62}$ CAW, II.13.12, Ogólny rozkaz operacyjny dowódcy armii „Poznań” z 6 września.

${ }^{63}$ M. Emmerling, dz. cyt., cz. 1, s. 106-107.

${ }^{64}$ Cyt za: A.Z. Józefowicz, Działania...., s. 5. Zob. też J. Mozio, Relacje uczestników walk września 1939, „Dziennik Ludowy”, 1982, nr 208. 
Messerschmittów nie zniszczył przeprawy ${ }^{65}$. Odnotowano jednak duże straty w ludności cywilnej, szczególnie wśród uciekinierów. Niemniej przeprawę wojsk polskich należy uznać za udaną. Poza Wielkopolską BK i 56 pp, na wschodni brzeg Warty przeszły także dywizjony 2 i 325 pal (bez 8 baterii, działającej na rzecz $60 \mathrm{pp}$ ), 25 dac (kpt. Edmund Wołkowiński), 9 bs (mjr Mieczysław Ostrowski) oraz gros $29 \mathrm{pp}$ (bez 1 batalionu).

W sztabie 30 DP we wsi Wólka o godzinie 14.30 szef sztabu, ppłk. Karl von Le Suire ${ }^{66}$ zreferował dotychczasową sytuację następująco:

6 batalion $\mathrm{km}$ przesunąt się do przodu tylko $1-2 \mathrm{~km}$. Ciężkie straty z powodu oddziałów nieregularnych (strzelców z koron drzew). OR 30 DP dziś rano poszedl $w$ rozsypkę. Teraz, po ciężkich stratach zebrany na nowo. 6 pp posuwa się do przodu, pierwsza linia jeszcze się nie zameldowata. Wroga artyleria nie odnaleziona. Ciężka artyleria w marszu, na pótnoc od Wólki. W użyciu 2 i 3 dywizjon 30 part. 26 pp wraz z 1 dywizjonem 30 part $w$ marszu na wieś Krępa. Straż przednia minęła właśnie siedzibę sztabu ${ }^{67}$.

Ze słów szefa sztabu 30 DP wynika, że walka o Uniejów wczesnym popołudniem nie była rozstrzygnięta i strona niemiecka odnotowała ciężkie straty. Zwraca też uwagę zaszeregowanie ad hoc ukrytych w koronach drzew żołnierzy polskich jako oddziałów nieregularnych.

Do południa przeprawa polskich oddziałów przez Wartę była ukończona, na wschodni brzeg rzeki i dalej w kierunku Dąbia n. Nerem, oprócz ułanów z Wielkopolskiej BK, przeszedł także $56 \mathrm{pp}$, wraz z innymi oddziałami i pododdziałami $25 \mathrm{DP}^{68}$. W szeregach polskich oddziałów wędrowali także uniejowianie. Niektórzy mieli możliwość zamiany kliku zdań z rodziną, inni bezsilnie thumili łzy, patrząc na płonące własne miasto. Rozkazy nie pozostawiały wyboru, należało maszerować dalej ${ }^{69}$. Około południa przeprawa była właściwie zakończona, co potwierdził wysłany przez mjr. E. Rukszana do Uniejowa kpt. Walenty Olejnik,

${ }^{65}$ Według W. Rezmera (dz. cyt., s. 182) Polakom udało się zestrzelić jeden z niemieckich samolotów. Niestety, 7 września Niemcy w tym rejonie nie stracili żadnego samolotu (por. M. Semmerling, dz. cyt., cz. I, s. 109; cz. II, s. 165-166). Polski badacz błędnie datował strącenie Heinkla He 111, które miało miejsce dzień wcześniej.

${ }^{66}$ Już jako generał major, stacjonując w Grecji 9 grudnia 1943 roku, Karl von Le Suire w zemście za rozstrzelanie przez partyzantów 80 żołnierzy niemieckich, rozkazał zniszczyć miejscowość Kalavryta i 25 innych wiosek oraz rozstrzelać wszystkich męskich mieszkańców w wieku od 15 do 65 lat. W masowym mordzie zginęło wtedy co najmniej 695 cywili. Pod koniec wojny trafił do radzieckiej niewoli, w której zmarł 18 czerwca 1954 roku. Źródło: http://www.lexikon-der-wehrmacht.de/Personenregister/L/LeSuireKarlv.htm. [dostęp 12.03.2020]

${ }^{67}$ BArch, RH26-30/1, Kriegstagebuch nr 1..., s. 36.

${ }^{68}$ B.I.37C, Relacja ppor. T. Polusa, k. 58-59.

${ }^{69}$ Zob. m.in. T. Wójcik, Żolnierz Września - Jan Wójcik, [w:] Zapamiętane..., s. 377. 
dowódca 2 kompanii ckm. Dowodzący 60 pp ppłk M. Frydrych ściśle wykonując rozkazy nakazał jednak swoim żołnierzom nadal trwać na posterunkach i dopiero o $15.00^{70}$ zarządził oderwanie się poszczególnych kompanii od przeciwnika. Odejście Polaków utrudniał nie tylko ostrzał artyleryjski, ale także i naloty z powietrza. Odwaga dowódcy 60 pp, który odszedł ze swoim sztabem jako ostatni z pola walki, podziałała mobilizująco na żołnierzy ${ }^{71}$. Pododdziały 60 pp zebrały się w organizacyjną całość w lesie Wielenin ${ }^{72}$, by stamtąd wieczorem dotrzeć do Dąbia, bez kontaktu z nieprzyjacielem z którym tak zaciekle walczył ${ }^{73}$. Odejście 60 pp osłaniać miał od strony Uniejowa 1 batalion 29 pp (mjr Stanisław Szczygieł) ${ }^{74}$.

Pierwszy dywizjon 25 pal, walcząc $w$ roli bezpośredniego wsparcia $60 \mathrm{pp}$, w ciągu 7 września zużył $\mathrm{w}$ rejonie Uniejowa 370 pocisków. Z pozycji bojowych zszedł o godzinie 14. 3 dywizjon tego pułku stał na pozycjach wraz z gros odwodowego 29 pp. 25 bateria plot., podobnie jak inne oddziały artyleryjskie, wieczorem rozwinęła się do obrony przeprawy przez Ner w Dąbiu. Dowódcy stan moralny i fizyczny żołnierzy określali jako dobry, podobnie jak stan dróg i pogody. Żołnierzom doskwierało zmęczenie, także wyżywienie tego dnia było opóźnione z powodu walk ${ }^{75}$.

Straty 60 pp w dniach 6-7 września wyniosły, według szacunków lekarza pułku, 60 zabitych, 115 rannych i 50 zaginionych $^{76}$. Zdobycz żołnierzy z Ostrowa Wlkp. była okazała i obejmowała: 30 rowerów, 3 działka ppanc, 4 motocykle, 3 ręczne km, zdobyto i zniszczono około 30 samochodów i 50 motocykli ${ }^{77}$.

Wycofanie się oddziałów polskich z okolic Uniejowa początkowo nie zostało przez Niemców zauważone, w sztabie 30 DP przygotowywano się do dalszej walki. Na podstawie materiałów dywizyjnych można odtworzyć informacje, jakie docierały po południu do siedziby sztabu $30 \mathrm{DP}$ w Wólce. O godzinie 16.40 nadszedł z niemieckich tyłów meldunek od ppor. Erhardta o ostrzale z da-

${ }^{70}$ Ppor. Leonard Pastusiak z 3 komp. w swoich wspomnieniach (PISM, B.I.37D, Relacja ppor. L. Pastusiaka, k. 21) podał godzinę 14.00.

${ }^{71} \mathrm{O}$ odwadze dowódcy $60 \mathrm{pp}$ wspominał kpt. Zygmunt Wroniecki, oficer łączności w sztabie 25 DP, PISM, B.I.37A, Relacja kpt. Z. Wronieckiego, k. 3.

${ }^{72}$ Według ppor. D. Serbińskiego z 7 komp. (PISM, B.I.37D, Relacja ppor. Dominika Serbińskiego, k. 40) w czasie formowania kolumny marszowej nie doliczono się $20 \%$ stanu osobowego 2 batalionu.

${ }^{73}$ K. Szepietowski, dz. cyt., s. 122-124; K. Kuźmiński, dz. cyt., s. 189-193; H. Breihaupt, dz. cyt., s. 18-19.

${ }^{74}$ CAW, II.13.13, Meldunek dowódcy 1 batalionu 29 pp do dowódcy 29 pp z 8 września.

${ }^{75}$ CAW, II.13.12, Meldunek sytuacyjny dowódcy artylerii dywizyjnej 25 DP z dnia 7 września.

${ }^{76}$ PISM, B.I.37D, Relacja ppor. lek. M. Natkańskiego, k. 5. K. Szepietowski (dz. cyt., s. 124), powołując się na zredagowany przez siebie meldunek sytuacyjny z dn. 8 września, podał następujące dane - polegli: 1 oficer, 7 podoficerów i 48 strzelców, ranni: 7 oficerów, 24 podoficerów i 70 strzelców.

${ }^{77}$ K. Szepietowski, dz. cyt., s. 124. 
chów w Niemysłowie ${ }^{78}$. Niestety znalazł on swój finał w masakrze na ludności cywilnej w tej miejscowości. O tej samej godzinie OR 30 DP był w drodze na Zalesie, $7 \mathrm{~km}$ na zachód od Wartkowic, prawdopodobnie rozpoznając możliwość manewru oskrzydlającego Uniejów i ewentualne zamiary Polaków, mogących zagrozić niemieckim kolumnom pomiędzy Wartkowicami a Łęczycą. O godzinie 17.59, po telefonicznym zapytaniu, dowódca 46 pp zameldował: najbardziej wysunięta część oddziatu $200 \mathrm{~m}$ przed Uniejowem. Pułk liczy się z zajęciem miejscowości $w$ najbliższym czasie ${ }^{79}$. Pułkowi nakazano pozostać w Uniejowie i wystawić wzmocnienia. Nie uzyskano natomiast połączenia z 6 pp. O godzinie 18.30 zdążający z przeprawy w Popowie w kierunku Poddębic 26 pp zameldował o ostrzelaniu go w m. Krępa przez oddziały nieregularne. Pięć minut przed godz. 19 dowódca 4 baterii 66 part meldował o tym, że Uniejów pali się. Kilkadziesiąt minut później, o godzinie 19.35, nadszedł meldunek od 46 pp, że jego szpica znajduje się w mieście ${ }^{80}$. Najwidoczniej wiadomość ta nie dotarła na czas do artylerzystów, bo 5 minut później wspomniana 4 bateria ostrzelała północny skraj Uniejowa. Natychmiast otrzymała rozkaz od szefa sztabu 30 DP, by wstrzymać ogień.

O godzinie 20.40 szefowie sztabów 30 DP oraz X KA ustalili podczas połączenia radiowego, że 46 pp pozostanie w Uniejowie aż do nadejścia 221 DP, następnie odmaszeruje w kierunku Łęczycy. Po dwudziestu minutach nadszedł jeszcze meldunek od OR, że na odcinku od Zalesia aż po Grabiszew nie ma polskich oddziałów. Niemcy wyraźnie nie zdawali sobie sprawy z faktu, że gros polskich oddziałów maszerowało na północ co najmniej kilka godzin wcześniej i to szosą odległą o mniej więcej $9 \mathrm{~km}$ na zachód od rozpoznawanego obszaru.

Pół godziny później, o 21.30 nadszedł meldunek od batalionu ppanc 30 DP, który do godziny 18.00 toczył potyczkę po drugiej stronie Warty, w Człopach. Zameldował też o nawiązaniu łączności z OR 221 DP.

Ostatnim polskim oddziałem, znajdującym się w bezpośrednim pobliżu Uniejowa, pozostawał przed wieczorem 1 batalion $29 \mathrm{pp}$ mjr. S. Szczygła. Zgodnie z rozkazem ze sztabu dywizji, batalion po wykonaniu zadania osłony odejść miał do Dąbia na rozkaz dowódcy macierzystego pułku. Mimo wysłania pisemnego meldunku, mjr S. Szczygieł nie otrzymał odpowiedzi. Wysłane przez 2 kompanię rozpoznanie doniosło, że inne oddziały własne już się z Uniejowa wycofały, a na północny wschód od Uniejowa dostrzeżono patrole niemieckie (z 6 pp, rozciągniętego w pasie między Szarowem na południu a Wieleninem na północy, 3 do $4 \mathrm{~km}$ na wschód od miasta). W tej sytuacji dowódca batalionu zwrócił się około godz. 18 do sztabu dywizji z prośbą o określenie, kiedy ma rozpocząć

${ }_{78}^{78}$ BArch, RH26-30/1, Kriegstagebuch nr 1..., s. 37.

79 Tamże, s. 38.

${ }^{80}$ Tym samym niewłaściwe okazały się domniemania W. Rezmera (dz. cyt., s. 195), a za nim T. Wójcika (Skrwawione..., s. 55), że oddziały niemieckie wkroczyły do Uniejowa 8 września po 6.30 rano. 
odwrót. Odpowiedni rozkaz dotarł do batalionu dwie godziny później ${ }^{81}$. Około godz. 22 batalion został ostrzelany w lesie Wielenin ogniem prowadzonym z rejonu lasu i wsi Orzeszków Kolonia (zob. mapa nr 2). Tuż po zejściu ze stanowisk, idący w kolumnie marszowej, kaliski batalion „,wpadł w zasadzkę ogniową i został rozproszony". Najwyraźniej zlekceważono meldunki własnego rozpoznania, donoszące o patrolach niemieckich zaobserwowanych na północny-wschód od Uniejowa, a więc niemal równolegle do pierwszego odcinka planowanej trasy przemarszu batalionu. Część pododdziałów dotarła do Dąbia, odległego o niecałe $10 \mathrm{~km}$, około godz. $2 \mathrm{w}$ nocy ${ }^{82}$. Pozostałe pododdziały zbierały się ze znaczną trudnością, żołnierze do Dąbia docierali grupkami, bądź plutonami aż do południa 8 września. Batalion stracił około 170 żołnierzy, porzucono też sporo sprzętu i uzbrojenia, mozolnie następnie zbieranego przez wysłane patrole ${ }^{83}$. Tej nocy poważnie ucierpiało morale żołnierzy. Niemcy pochwycili też jeńców. Dowódca pułku, ppłk Florian Gryl, stwierdził, że batalion „doznał ciężkich strat”. Winą obciążył dywersantów ${ }^{84}$, taki pogląd przeważał dotąd w polskiej historiografii. W rzeczywistości jednak, jak wynika to z mapy sztabu 30 DP, był to niezwykle skutecznie przeprowadzony atak 6 kompanii niemieckiego 6 pp (dowódca pododdziału ppor. Günther von Fragstein und Niemsdorff) ${ }^{85}$.

Jakiemukolwiek udziałowi dywersantów w tym ataku przeczy także sporządzone dn. 18 października 1939 roku „Sprawozdanie z udziału 30 DP w wojnie z Polską we wrześniu 1939 roku". Stwierdzono w nim, że mniejszość niemiecka

${ }^{81}$ CAW, II.13.13, Meldunek dowódcy 1 batalionu 29 pp do dowódcy 29 pp z 8 września.

${ }^{82}$ T. Pietrzak, dz. cyt., s. 98-101.

${ }^{83}$ CAW, II.13.13, Raporty bojowe dowódców kompanii 60 pp z 8 września. 1 kompania straciła 61 ludzi, $2-55$, a 3 około 50. Nie ma jasności, jaką część stanowią polegli, a jaką zaginieni żołnierze. Wydaje się jednak, że polegli stanowili wyraźnie mniejszą część, rzędu raczej kilkunastu osób (świadczy o tym brak pochówków licznej grupy żołnierzy 29 pp na cmentarzach w gminie Uniejów). We wspomnieniach (zob. m.in. B. Trzeszczak, Wspomnienia ze szlaku bojowego II Batalionu 29 Pułku Strzelców Kaniowskich we wrześniu 1939 roku, [w:] Udziat..., s. 369; T. Pietrzak, dz. cyt, s. $100 \mathrm{i}$ in.) przewija się wątek ,znacznych” strat w ludziach, wynikają one jednak ze śladowych, za to pełnych emocji, informacji, jakimi dysponowali ich autorzy. W nieprecyzyjnym Wykazie poległych żotnierzy 29 Pułku Strzelców Kaniowskich (Udział..., s. 326-330) wymieniony jest jedynie ppor. Eryk Baumert, dowódca 2 plutonu 1 kompanii km. Tadeusz Pietrzak (dz. cyt., s. 100-101) wspomina poległego tej nocy pchor. Władysława Duxa, swego przyjaciela. W świetle raportów straty opisane bez bliższego wyszczególnienia przez P. Bauera i B. Polaka (dz. cyt., s. 228) wydają się być przesadzone (400 żołnierzy). Zob. też PSZ, s. 542.

${ }^{84}$ Dowódca pułku, ppłk. F. Gryl, jednoznacznie wskazywał na dywersantów, PISM, B.I.37B, F. Gryl, Boje 29 Pułku Strzelców Kaniowskich, k. 41. Nie można wykluczyć, że wpływ na tak kategoryczną identyfikację miały wydarzenia z dnia poprzedniego, gdy żołnierze 29 pp podczas marszu z Turku do Uniejowa pochwycili grupę dywersantów. Także i w Uniejowie, jeszcze przed wybuchem wojny, zauważono nieznanych nikomu młodych mężczyzn, mówiących po niemiecku, ubranych w cywilne rzeczy i przebywających w domach miejscowych obywateli narodowości niemieckiej; A.Z. Józefowicz, Uniejów..., s. 22. Zob. też PISM, B.I.37B, Relacja ppor. A. E. Lachetty, k. 7; tamże, Relacja por. T. Sznajdera, k. 10-14.

${ }^{85}$ BArch, RH26-30/1, Kriegstagebuch nr 1..., Karte 7c. Lage am 7.9 abends (ryc. 3, mapa rejonu ze stanem z wieczora 7 września). 
występowała tylko jako uchodźcy. Aktywnej pomocy w walkach, jak jest to znane z innych źródel, w obszarze działania 30 DP nie stwierdzono ${ }^{86}$.

Mniej dramatyczny los spotkał towarzyszącą batalionowi 8 baterię 25 pal. Tej nocy w Dąbiu kontrolując stan pododdziałów dowódca 25 pal, ppłk A. Wojtanowicz, stwierdził nieobecność 8 baterii. Odnaleziony na kwaterze jej dowódca, kpt. J. Turaszwili, nie umiał wyjaśnić tej sytuacji. Widocznie dowódca baterii - skądinąd dobry oficer - ulegt panice, stracit głowę i nie zawiadomit oficera ogniowego o zejściu ze stanowiska - wywnioskował dowódca pułku. Ostatecznie baterię w pełnym składzie przyprowadził do Dąbia o świcie oficer ogniowy, ppor. rez. Tadeusz Motylewski: dzięki jego wybitnej inteligencji, szybkości, orientacji i decyzji bateria została uratowana ${ }^{87}$.

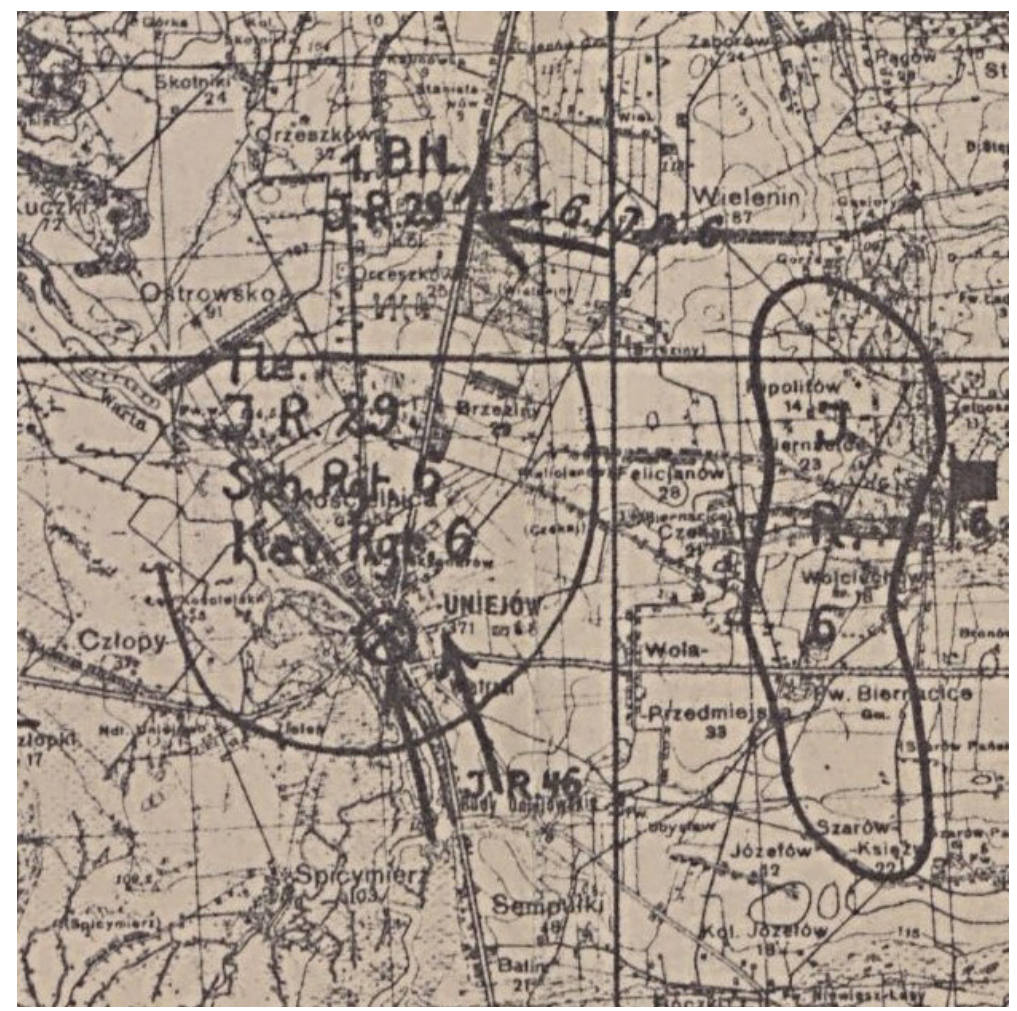

Ryc. 3. Fragment mapy sztabowej niemieckiej $30 \mathrm{DP}$

z zaznaczonym atakiem $6 / 6$ pp na 1 batalion $29 \mathrm{pp}$

Źródło: BArch, RH26-30/1, Kriegstagebuch nr 1. 30 Infanterie - Division, Karte 7c. Lage am 7.9 abends (załącznik, mapa rejonu ze stanem z wieczora 7 września)

${ }^{86}$ BArch, RH26-37/6966, Erfahrungsbericht über den Poleneinsatz.

${ }^{87}$ A. Wojtanowicz, dz. cyt., s. 7. Podporucznik T. Motylewski poległ kilka dni później pod Łęczycą. 
Sukces Niemców, odniesiony w lesie Wielenin, wyraźnie przypominał wydarzenia spod Balina sprzed zaledwie doby. W obydwu przypadkach poruszające się kolumny wojska (w Balinie niemieckiego, w Orzeszkowie polskiego) wpadły w zasadzkę przeciwnika, odnosząc duże straty i popadając w rozproszenie. Nie można też oprzeć się wrażeniu, że nieszczęsny batalion mjr. S. Szczygła padł ofiarą nie tylko ognia niemieckiej kompanii, ale także pewnego chaosu decyzyjnego na szczeblu dywizyjnym. Nie jest bowiem jasne, czyjej bezpośredniej zwierzchności podlegał oddział tego wieczora i od kogo miał otrzymać rozkaz do odejścia (dowództwa dywizji, macierzystego pułku, czy dowódcy OW). Uzasadnione jest domniemanie, że w przypadku otrzymania jasnego rozkazu do odejścia w godzinach popołudniowych, po wymarszu $60 \mathrm{pp}, 1$ batalion odmaszerowałby szosą do Dąbia zanim pojawił się w lesie obok Orzeszkowa Kolonii pododdział $6 \mathrm{pp}^{88}$.

Bilans walk pod Uniejowem, trwających prawie dobę, był dla obu stron satysfakcjonujący. Z perspektywy polskiej Oddział Wydzielony bohaterskiego ppłk. Mariana Frydrycha wypełnił w całości postawione przed nim zadania. Wielkopolscy żołnierze umożliwili w przewidywanym czasie przeprawę Wielkopolskiej Brygady Kawalerii, pospiesznie kierowanej z rejonu Słupcy aż pod Łęczycę ${ }^{89}$ oraz macierzystej 25 DP. Miało to kluczowe znaczenie w kontekście decyzji dowódcy armii „Poznań”, gen. T. Kutrzeby, o podjęciu ofensywnego działania nad Bzurą. Gdyby Niemcy pod Uniejowem odcięli drogę na wschód w kierunku Warszawy, kluczowe dla I fazy bitwy nad Bzury oddziały Wielkopolskiej BK i 25 DP przeprawiałyby się przez Wartę albo pod Uniejowem wpław pod bezpośrednim ogniem niemieckim, albo musiały w niedogodnych warunkach przewędrować na północ i szukać przeprawy w rejonie Koła. Każde z tych działań oznaczałoby możliwe poważne straty w ludziach i sprzęcie, ponadto znaczące opóźnienie ruchów wojsk, konieczność rewizji zamiarów działania, a wobec postępów niemieckiej 8 armii, nawet uniemożliwienie armii „Poznań” wykonania rozkazów Naczelnego Wodza o odejściu na linię Wisły.

Jak wspomniano, także Niemcy byli zadowoleni z wyniku walk pod Uniejowem. Celem działań lewoskrzydłowej 30 DP w tym rejonie było w pierwszej kolejności zapewnienie możliwości przeprawy przez Wartę oddziałom tyłowym, będącym odwodem GA, w szczególności zaś 221 DP, co zostało wykonane. Natomiast dowództwo szczebla armijnego, skoncentrowane na działaniach szybkich WJ i odcięciu polskiego marszu na wschód w rejonie Łęczycy - Sochaczewa, nie doceniło znaczenia mostów w rejonie Uniejowa dla armii „Poznań”. Podobnie lekceważący stosunek do analizy zamiarów polskich przyniósł 8 armii gorzką lekcję w rejonie Łęczycy zaledwie kilka dni później.

${ }^{88}$ Kwestię podległości 1 batalionu 29 pp szczegółowo analizuje W. Rezmer, dz. cyt. s. 182, p. 38.

${ }^{89}$ Zob. przemyślenia i wnioski dowódcy Wielkopolskiej BK, gen. bryg. Romana Abrahama (Roman Abraham - wspomnienia wojenne znad Warty i Bzury, Warszawa 1990, s. 47-50). 
Warto podkreślić, że żołnierze Wehrmachtu nie zdobyli Uniejowa w boju, ale zajęli miasto w kilka godzin po opuszczeniu go przez wojska polskie.

Dla obu stron, zarówno dla żołnierzy kaliskiej 25 DP, jak i niemieckiej 30 DP, walki pod Uniejowem w dn. 6 i 7 września były pierwszym poważnym starciem w czasie wojny. Rozpatrując je z punktu widzenia rzemiosła wojennego przyniosły one zasłużone laury dla żołnierzy polskich. Zdołali oni bowiem wykonać postawione rozkazy w obliczu silniejszego przeciwnika. „Gruppe Adelhoch” obejmowała najsilniejsze i najnowocześniejsze zmotoryzowane pododdziały, jakimi dysponował gen. K. von Briesen, będące zmotoryzowaną ,pięścią”, mającą nokautować zastanego na swej drodze przeciwnika. W swoim pierwszym egzaminie dywizyjna awangarda poniosła wyraźną porażkę. Zadecydowała o tym bitność Polaków, ich frontowa zuchwałość, jakość wyszkolenia, mądrość dowódców oraz, co oczywiste, patriotyzm. Ufni w potęgę swej armii, jej techniczną przewagę, przepojeni hitlerowską ideologią Niemcy otrzymali bolesną lekcję, powtórzoną pod Łęczycą. Tę dobrą ocenę wojsk 25 DP potwierdzają walki toczone 7 września, w obliczu jeszcze silniejszego nieprzyjaciela.

Walki w rejonie Uniejowa pokazały dobitnie wartość polskiego żołnierza, przewyższającego pod względem wyszkolenia, odwagi i determinacji niemieckiego najeźdźcę. Także i w tym wojskoznawczym, a nie tylko chronologicznym, kontekście, stanowiły preludium bitwy nad Bzurą.

\section{Wykaz skrótów (pominięto skróty powszechnie używane oraz stopnie wojskowe)}

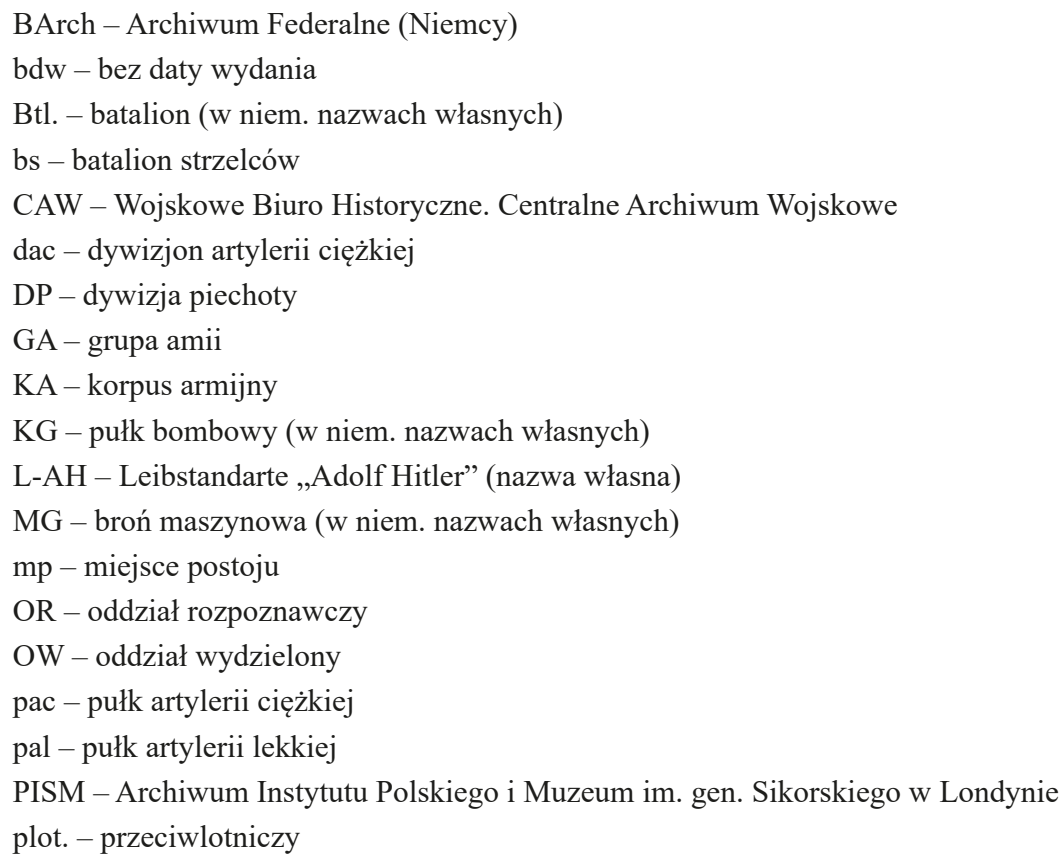


$\mathrm{pp}-$ pułk piechoty

ppanc. - przeciwpancerny

psk - pułk strzelców konnych

PSZ - Polskie Siły Zbrojne (tytuł)

WJ - wielkie jednostki

\section{Bibliografia}

\section{Źródla}

Instytut Polski i Muzeum im. gen. Sikorskiego w Londynie (PISM). Relacje z Kampanii 1939 roku

B.I.37A 25 Dywizja Piechoty - Sztab

B.I.37B 25 Dywizja Piechoty - 29 Pułk Piechoty

B.I.37C 25 Dywizja Piechoty - 56 Pułk Piechoty

B.I.37D 25 Dywizja Piechoty - 60 Pułk Piechoty

B.I.37F 25 Dywizja Piechoty - 25 Pułk Artylerii Lekkiej, 25 Dywizjon Artylerii Ciężkiej, 25 Bateria Artylerii Przeciwlotniczej, Kawaleria Dywizyjna

B.I.37G 25 Dywizja Piechoty - Saperzy i Służby

Rosyjsko-niemiecki projekt digitalizacji niemieckich dokumentów w archiwach Federacji Rosyjskiej (Российско-германский проект по оцифровке германских документов в архивах Российской Федерации) https://wwii.germandocsinrussia.org/

Niemieckie Archiwum Federalne (Bundesarchiv, BArch)

RH26-37/6966, Erfahrungsbericht über den Poleneinsatz

RH26-30/1, Kriegstagebuch nr 1. 30 Infanterie - Division

RH37/6582, Kriegstagebuch vom Polenfeldzug des M.G. - Bataillion 6 (mot) u. später Krad Schtz Btl. 40

Wojskowe Biuro Historyczne - Centralne Archiwum Wojskowe (CAW)

II.13.12. Materiały z Kampanii Wrześniowej. Zespół akt armii „Poznań”, Rozkazy i meldunki różne.

II.13.13. Materiały z Kampanii Wrześniowej. Zespół akt armii „Poznań”, Rozkazy i meldunki różne.

II.13.14, Materiały z Kampanii Wrześniowej. Odpis dziennika Józefa Walzela dokonany i przetłumaczony przez oficera wywiadu 25 DP kpt. Jewasińskiego.

IX.2.3.134, Kolekcja Akt Wojskowego Biura Badań Historycznych, Wojna obronna Polski 1939, 6 Pułk Strzelców Konnych im. Hetmana Wielkiego Koronnego Stanisława Żółkiewskiego.

\section{Wspomnienia drukowane i opracowania}

Baranowski J., Wojna obronna Polski w 1939 r. i lata okupacji hitlerowskiej, [w:] J. Szymczak (red.), Uniejów. Dzieje miasta, Łódź-Uniejów 1995.

Bauer P., Polak B., Armia Poznań w wojnie obronnej 1939, Poznań 1982.

Böhler J., Zbrodnie Wehrmachtu w Polsce. Wrzesień 1939. Wojna totalna, Kraków 2009. 
Breihaupt H., Die Geschichte der 30. Infanterie-Division 1939-1945, Bad Nauheim 1955.

Cynk J.B., Polskie Lotnictwo Myśliwskie w boju wrześniowym, Gdańsk 2000.

Emmerling M., Luftwaffe nad Polska 1939. Cz. I: Jagdflieger, Gdynia 2002.

Emmerling M., Luftwaffe nad Polska 1939. Cz. II: Kampfflieger, Gdynia 2005.

Geschichte des Infanterie - Regiments 46 1. Oktober 1934 bis 8 Mai 1945, Teil II, Kameradschaft 1988.

Gliederung und Stellenbesetzung der Wehrmacht for wargaming \& historical research: http://gliederungundstellenbesetzung.blogspot.com [dostęp: 12.03.2020].

Gnat-Witeska Z., 6 Pułk Strzelców Konnych, Pruszków 1988.

Jagodziński Z., 60 Pułk Piechoty Wielkopolskiej, Ostrów Wielkopolski 2016.

Józefowicz A.Z., Działania wojenne w Uniejowie we wrześniu 1939 roku, „W Uniejowie” 2005, $\mathrm{nr} 23$.

Józefowicz A.Z., Uniejów w przededniu II wojny światowej, [w:] T. Wójcik (red.), Zapamiętane z Brückstädt. Wspomnienia wojenne mieszkańców ziemi uniejowskiej, Uniejów 2014.

Korczak J., Cóżeś ty za pani... O walkach armii „Poznañ” 1-19 września 1939 r., Poznań 1988.

Kozłowski W., Niedoszła akcja armii „,Poznań” między Prosna a Warta w 1939 r., „Acta Universitatis Lodziensis. Folia Historica" 1981, nr 3.

Kuźmiński K., Dziennik dowódcy kompanii, [w:] E. Makowski (opr.), Wspomnienia z wrześniowych dni. Wielkopolanie o kampanii wojennej 1939 roku, Poznań 1975.

Lexikon der Wehrmacht: http://www.lexikon-der-wehrmacht.de/Personenregister/B/BorgmannH. htm [dostęp 12.03.2020]

Lexikon der Wehrmacht: http://www.lexikon-der-wehrmacht.de/Personenregister/L/LeSuireKarlv [dostęp 12.03.2020]

Ludwigs A. (red.), Pionier-Bataillon 30. Geschichte 1936-1945, Pionier-Kameradschaft, Lübeck bdw.

Makowski E. (opr.), Wspomnienia z wrześniowych dni. Wielkopolanie o kampanii wojennej 1939 roku, Poznań 1975.

Mozio J., Relacje uczestników walk września 1939, „Dziennik Ludowy” 1982, nr 208.

Pacanowski T., Pierwszy poważny kontakt mego uczestnictwa $w$ działaniach wojennych 1939 roku (fragment), [w:] Z. Jagodziński, 60 Pułk Piechoty Wielkopolskiej, Ostrów Wielkopolski 2016.

Pietrzak T., Wrześniowe dni, opr. J. Pereświet Sołtan, Turek-Kalisz 2005.

Polak B. (red.), Udziat społeczeństwa ziemi kaliskiej w wojnie obronnej 1939 roku, Kalisz 1979.

Polskie Sity Zbrojne w drugiej wojnie światowej, t. I, Kampania wrześniowa 1939, cz. 2, Przebieg działań od 1 do 8 września, Londyn 1986.

Rezmer W., Armia „Poznań” 1939, Bellona, Warszawa 1992.

Roman Abraham - wspomnienia wojenne znad Warty i Bzury, Warszawa 1990.

Sawicka-Miszewska D., Sawicki L., Sawicki R., Tadeusz Sawicki (1912-1939) - lotnik polegty na ziemi szadkowskiej. Wspomnienie rodziny, „Biuletyn Szadkowski” 2017, t. 17.

Szepietowski K., 60 pułk piechoty na szlaku bojowym Ostrów Wlkp. - Warszawa, [w:] Żotnierze września, Warszawa 1971.

Szymański W., Z kart historii. Wrzesień 1939 r. - Uniejów w ogniu walk, „W Uniejowie” 2000, nr 3.

Szymczak J. (red.), Uniejów. Dzieje miasta, Łódź-Uniejów 1995. 
Tomaszewski L., Wspomnienia z działań 60 pułku piechoty we wrześniu 1939 r., [w:] B. Polak (red.), Udziat społeczeństwa ziemi kaliskiej w wojnie obronnej 1939 roku, Kalisz 1979.

Trzeszczak, Wspomnienia ze szlaku bojowego II Batalionu 29 Pułku Strzelców Kaniowskich we wrześniu 1939 roku, [w:] B. Polak (red.), Udziat społeczeństwa ziemi kaliskiej w wojnie obronnej 1939 roku, Kalisz 1979.

Wojtanowicz A., Wspomnienia artylerzysty. O działaniach bojowych 25 pal ziemi kaliskiej w kampanii wrześniowej 1939 roku, „Ziemia Łęczycka” 1960, nr 10.

Wójcik T., Skrwawione miasto. Uniejów i jego region w czasie wojny obronnej 1939 roku, „Biuletyn Uniejowski” 2018, t. 7.

Wójcik T. (red.), Zapamiętane z Brückstädt. Wspomnienia wojenne mieszkańców ziemi uniejowskiej, Uniejów 2014.

Wójcik T., Żotnierz Września - Jan Wójcik, [w:] T. Wójcik (red.), Zapamiętane z Brückstädt. Wspomnienia wojenne mieszkańców ziemi uniejowskiej, Uniejów 2014.

Zawilski A., Bitwa nad Bzura, Warszawa 1969.

\title{
BATTLE OF 6-7 SEPTEMBER 1939 BETWEEN LIEUTENANT COLONEL MARIAN FRYDRYCH'S DETACHMENT WITH WEHRMACHT'S $30^{\mathrm{TH}}$ INFANTRY DIVISION TO KEEP THE BRIDGE IN UNIEJÓW
}

\begin{abstract}
Summary
During the defensive war in September 1939, Uniejów and its region were the site of fierce fighting between the troops of the Polish Army "Poznań" and German $8^{\text {th }}$ Army. The tactical significance of Uniejów was due to the bridge across the river Warta, which was of key importance for Polish troops marching from the state border to Warsaw. The fights took place on 6-7 September. The Detachment of Marian Frydrych, commanding officer of $60^{\text {th }}$ Regiment of Wielkopolska Infantry of $25^{\text {th }}$ Infantry Division prevented German troops of $30^{\text {th }}$ Infantry Division from seizing and destroying the bridge, which meant safe crossing for Polish soldiers. The authors are the first in Polish historiography to make use of documents from German military archives and to present the fights from the German army perspective. It also was possible to clear up the question of defeating $1^{\text {st }}$ Battalion of $29^{\text {th }}$ Kaniov Rifle Regiment near Uniejów in the evening of 7 September.
\end{abstract}

Keywords: defensive war, September 1939, Uniejów, Balin, Army „Poznań”, $8^{\text {th }}$ Army (Germany), $25^{\text {th }}$ Infantry Division, $30^{\text {th }}$ Infantry Division (Germany), lieutenant colonel Marian Frydrych, general major Kurt von Briesen (Germany), $60^{\text {th }}$ Infantry Regiment

Data nadesłania artykułu: kwiecień 2020

Data akceptacji: maj 2020 